\title{
The 1987 Whittier Narrows Earthquake Sequence in Los Angeles, Southern California: Seismological and Tectonic Analysis
}

\author{
EGILL HAUKSSON \\ Department of Geological Sciences, University of Southern California, Los Angeles \\ LUCILE M. JONES \\ U.S. Geological Survey, Pasadena, California
}

\begin{abstract}
The October 1, 1987, Whittier Narrows earthquake $\left(M_{L}=5.9\right)$ was located at $34^{\circ} 2.966^{\prime} \mathrm{N}$, $118^{\circ} 4.86^{\prime} \mathrm{W}$, at a depth of $14.6 \pm 0.5 \mathrm{~km}$ in the northeastern Los Angeles basin. The focal mechanism of the mainshock derived from first motion polarities shows pure thrust motion on west striking nodal planes with dips of $25^{\circ} \pm 5^{\circ}$ and $65^{\circ} \pm 5^{\circ}$, respectively. The aftershocks define an approximately circular surface that dips gently to the north, centered at the hypocenter of the mainshock with a diameter of $4-6 \mathrm{~km}$. Hence the spatial distribution of the mainshock and aftershocks as well as the focal mechanisms of the mainshock indicate that the causative fault was a $25^{\circ}$ north dipping thrust fault striking west and is confined to depths from 10 to $16 \mathrm{~km}$. Although most of the 59 aftershock focal mechanisms presented here document a complex sequence of faulting, they are consistent with deformation of the hanging wall caused by the thrust faulting observed in the mainshock. A cluster of reverse faulting events on north striking planes occurred within hours after the mainshock, $2 \mathrm{~km}$ to the west of the mainshock. The largest aftershock $\left(M_{L}=5.3\right)$ occurred on October 4 and showed mostly right-lateral faulting on the same north-northwest striking plane within the hanging wall. Similarly, several left-lateral focal mechanisms are observed near the eastern edge of the mainshock rupture. The earthquake and calibration blast arrival time data were inverted to obtain two refined crustal velocity models and a set of station delays. When relocating the blast using the new models and delays, the absolute hypocentral location bias is less than $0.5 \mathrm{~km}$. The mainshock was followed by nearly 500 locatable aftershocks, which is a small number of aftershocks for this magnitude mainshock. The decay rate of aftershock occurrences with time was fast, while the $b$ value was low $(0.67 \pm 0.05)$ for a Los Angeles basin sequence.
\end{abstract}

\section{INTRODUCTION}

The moderate-sized $\left(M_{L}=5.9\right)$ Whittier Narrows earthquake occurred in the east Los Angeles metropolitan area in southern California at 1442 (UT) on October 1, 1987 (Figure 1), and caused three direct fatalities and substantial damage to structures in many communities in Los Angeles and Orange counties [Hauksson et al., 1988].

The data analyses carried out in this paper are more detailed than those from Hauksson et al. [1988]. The blast arrival time data [Perkins, 1988] that were not available in the previous study are used here to constrain new velocity models. The new velocity models and station delays provide $0.5-1.0 \mathrm{~km}$ shallower focal depths for most of the aftershocks, while the epicenters are almost identical within $0.5 \mathrm{~km}$. Detailed aftershock statistics are also derived to facilitate comparison with other sequences, although such a comparison is not the subject of this paper. To analyze the deformation caused by this sequence, 57 new single-event focal mechanisms are determined. The results of this more detailed study mostly confirm the conclusions reached by Hauksson et al. [1988] with three exceptions. First, Hauksson et al.

Copyright 1989 by the American Geophysical Union.

Paper number 89JB00111.

0148-0227/89/89JB-00111\$05.00
[1988] suggested that the steeply dipping fault, which caused the largest aftershock, caused earthquakes within both the hanging wall and the footwall of the mainshock fault. The new relocations of the aftershocks show that this fault is only seismically active within the hanging wall. Second, Hauksson et al. [1988] showed that the aftershock zone of the largest aftershock was from 14.5 to $11 \mathrm{~km}$ depth. The new relocations of these aftershocks show this zone extending from 15 to $9 \mathrm{~km}$ depth. Third, the focal depths of the mainshock and largest aftershock changed from 14 and $12 \mathrm{~km}$ [Hauksson et al., 1988] to 14.6 and $13.3 \mathrm{~km}$, respectively.

The Whittier Narrows earthquake is the largest earthquake to occur west of the San Andreas fault in southern California since the $1971\left(M_{w}=6.6\right)$ San Fernando earthquake. The Whittier Narrows earthquake was located in the northeastern corner of the Los Angeles basin, halfway between the surface traces of the Raymond and Whittier faults. The Raymond fault, $5-10 \mathrm{~km}$ north of the epicenter, is a part of the Santa Monica-HollywoodRaymond fault system, a west striking and north dipping reverse fault system. Before the occurrence of the Whittier Narrows earthquake this fault system was considered to be the southernmost margin of the frontal faults of the Transverse Ranges [Crook et al., 1987]. The earthquake is also located $5-10 \mathrm{~km}$ to the north of the mapped terminus of the northwest striking Whittier fault. Where 


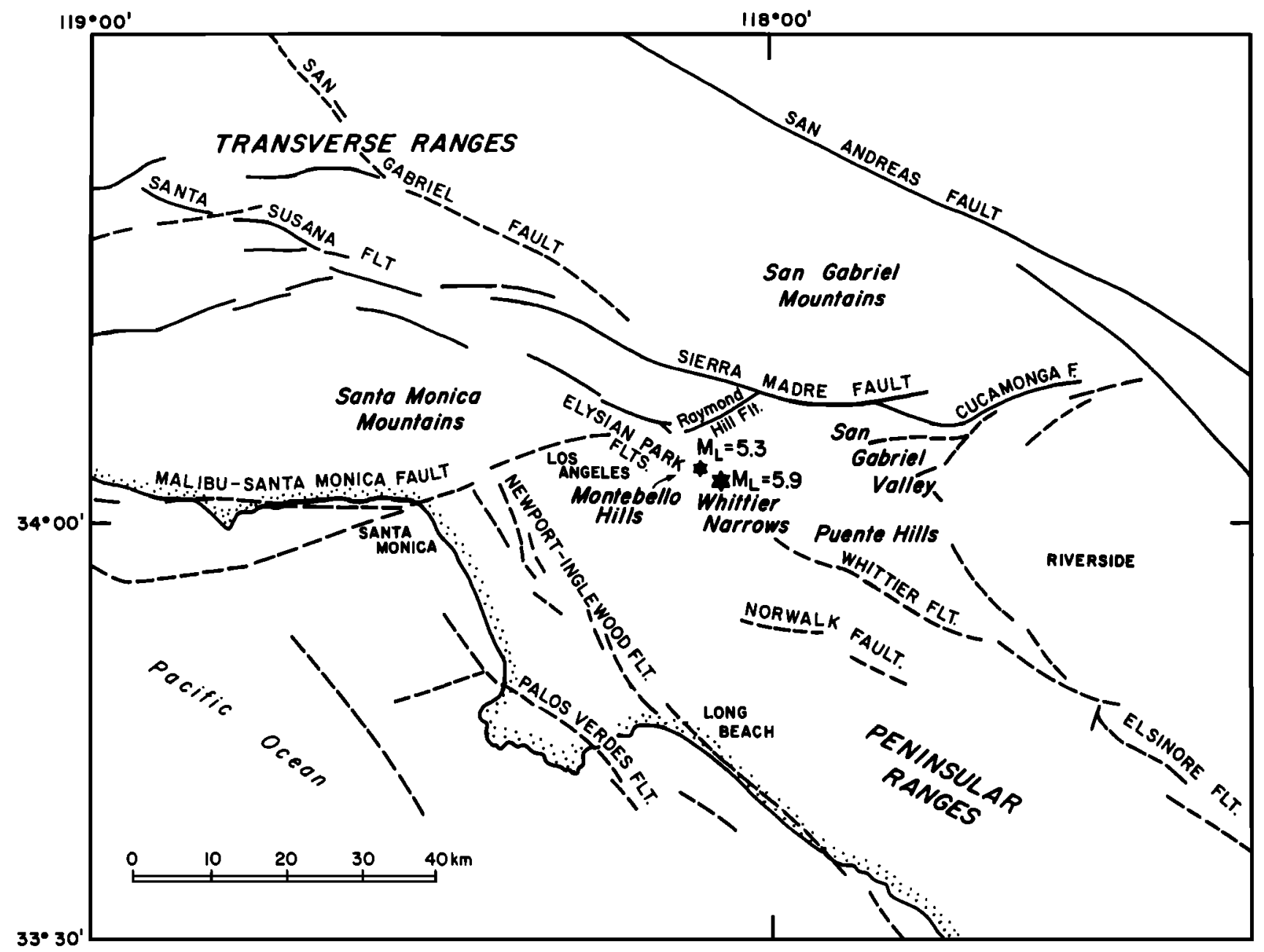

Fig. 1. An overview of the Los Angeles basin and adjacent regions, southem California. Epicenters of the Whittier Narrows mainshock $\left(M_{L}=5.9\right)$ and largest aftershock $\left(M_{L}=5.3\right)$ are shown. Faults located to the south of the epicenter of the Whittier Narrows earthquake accommodate mostly strike-slip movement, whereas except for the San Andreas fault, faults that are located to the north accommodate mostly reverse or thrust movement.

it is best exposed in the Puente Hills, the Whittier fault is dominantly a steeply northeast dipping, strike-slip fault with a small reverse component [Yerkes et al., 1965].

The Whittier Narrows earthquake was caused by rupture on a gently north dipping, west striking thrust fault. Thus it was not associated with a strike-slip fault south of the epicenter, such as the Whittier fault. It was also located well south of the mapped reverse and thrust faults of the Transverse Ranges and thus occurred on a structure not expressed at the surface. As a thrust faulting earthquake in what previously has been thought to be a strike-slip to oblique-reverse regime, the occurrence of the Whittier Narrows earthquake requires that existing interpretations of the neotectonics of the Los Angeles basin and the southern margin of the central Transverse Ranges [e.g., Yerkes et al., 1965; Morton and Yerkes, 1987] be modified.

Available geological evidence and the occurrence of the Whittier Narrows earthquake suggest that a 10 to $15 \mathrm{~km}$ wide transition zone of seismogenic blind thrust faults (here called the Elysian Park fault system) exists between the west striking reverse faults of the Transverse Ranges to the north and the northwest striking strike-slip faults of the Peninsular Ranges to the south. These blind thrust faults do not emerge at the ground surface [Davis et al., this issue]. Such blind fault systems are overlain by a cover or a roof sequence that deforms synchronously [Dunne and Ferrill, 1988]). This coseismic deformation was observed following the Whittier Narrows earthquake as domal uplift over an area of $5-8 \mathrm{~km}$ diameter with a peak uplift of $50 \mathrm{~mm}$ at the apex [Lin and Stein, this issue].

The importance of blind thrusts under anticlines in seismic hazards analysis has recently been highlighted by the occurrence of several earthquakes in well-instrumented areas, such as the $1983\left(M_{w}=6.5\right)$ Coalinga earthquake [Eaton, 1985], the $1985\left(M_{S}=6.7,6.9\right)$ Nahanni earthquakes [Wetmiller et al.,1988], and the 1987 $\left(M_{L}=5.9\right)$ Whittier Narrows earthquake [Hauksson et al., 1988]. All of these earthquakes occurred on blind thrusts with anticlines as the sole surface expression of the faults. These earthquake hazards are very important because 


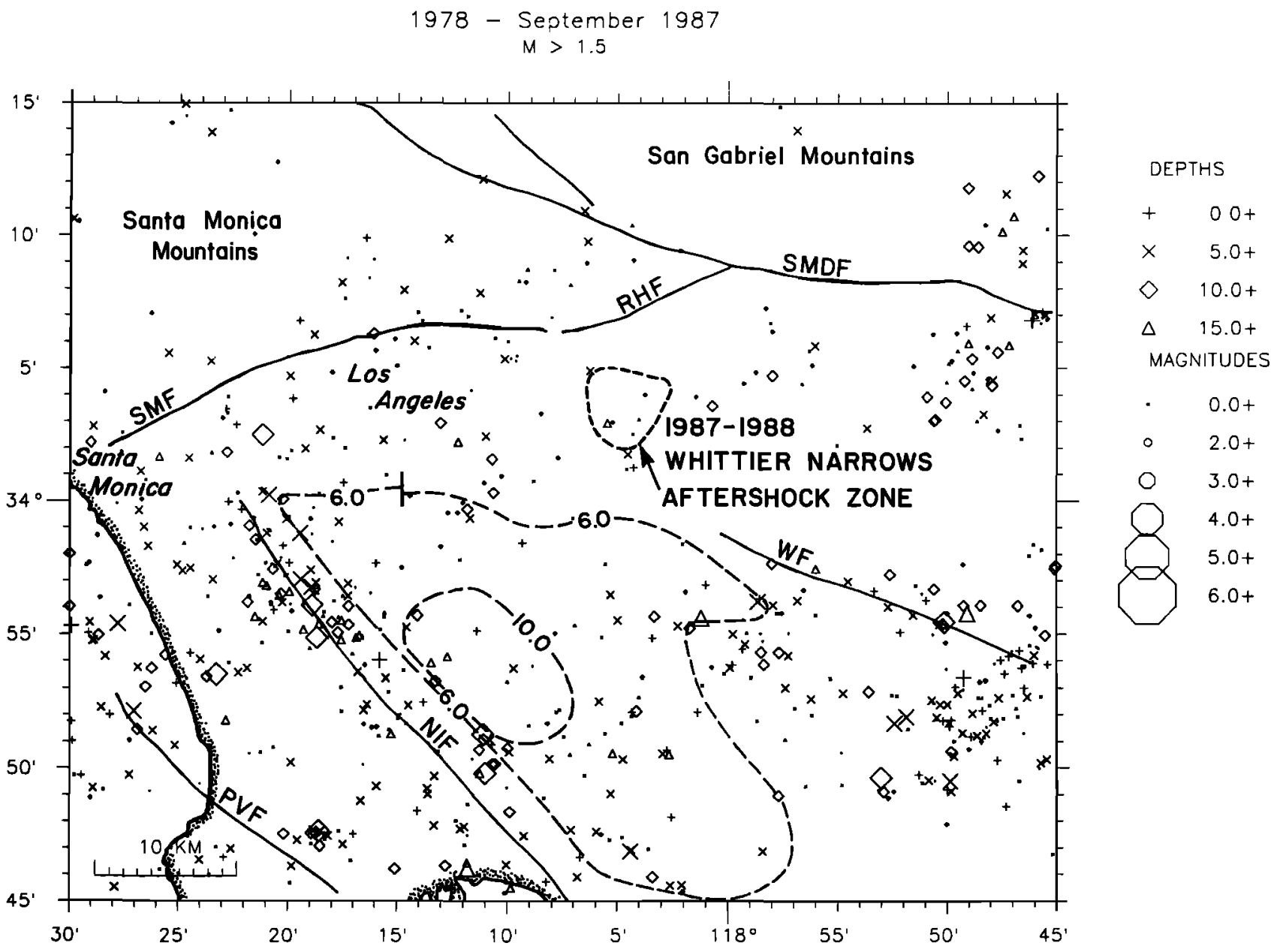

Fig. 2. Earthquakes $(M \geq 1.5)$ in the Los Angeles basin from 1978 to September 1987 as recorded by the CIT/USGS Southern California Seismic Network and the USC Los Angeles Basin Seismic Network. Symbol size is proportional to magnitude and symbol type is coded according to depth. The Whittier Narrows aftershock zone is enclosed with a dashed curve. WF, Whittier fault; RHF, Raymond fault; SMDF, Sierra Madre fault; NIF, Newport-Inglewood fault; PVF, Palos Verdes fault; and the SMF, Santa Monica fault. The contour lines 6.0 and 10.0 are the $6 \mathrm{~km}$ and $10 \mathrm{~km}$ depth to basement contours in the Los Angeles basin, respectively [Yerkes et al., 1965]. The approximate outline of the Whittier Narrows aftershock zone is also shown.

anticlinal structures are common in compressional tectonic environments as well as in some strike-slip environments [e.g., Page, 1981]. These hazards, however, are difficult to evaluate because the causative faults do not extend to the surface, and thus slip rates must be inferred from contraction or uplift rates or the use of mapped deformation in the cover or roof sequence above the blind thrust to infer the slip rate on the buried causative fault [e.g., Davis et al., this issue].

The Whittier Narrows earthquake was not preceded by any obvious increase in background seismicity within the Los Angeles basin or nearby areas [Hauksson et al., 1988]. All $M_{L} \geq 1.5$ earthquakes for 10 years preceding the event are shown in Figure 2. The aftershock zone is relatively aseismic compared to many other more active areas within the Los Angeles basin. The more seismically active areas are the Newport-Inglewood fault zone and the area southwest of the Whittier fault. The northern Los Angeles basin also shows a moderate level of activity, while the deepest part of the basin and the Santa Monica mountains are almost aseismic.

\section{EARTHQUAKe Data}

The Whittier Narrows earthquake sequence was recorded by the California Institute of Technology/U.S. Geological Survey (CIT/USGS) Southern California Seismic Network and the University of Southern California (USC) Los Angeles Basin Seismic Network (Figure 3). The CIT/USGS network provided coverage to the east, while the USC network provided coverage to the west. The closest permanent seismic station (TCC) is located $10 \mathrm{~km}$ south-southeast of the sequence. Both networks are digitally recorded at 100 samples per second (sps) using CUSP event detecting software, except for some cases where the CIT/USGS network is recorded at 62.5 sps [Johnson, 1983; Given et al., 1987]. Over 95\% of the arrival time and first motion polarities used in this study were obtained from these two permanent networks. 


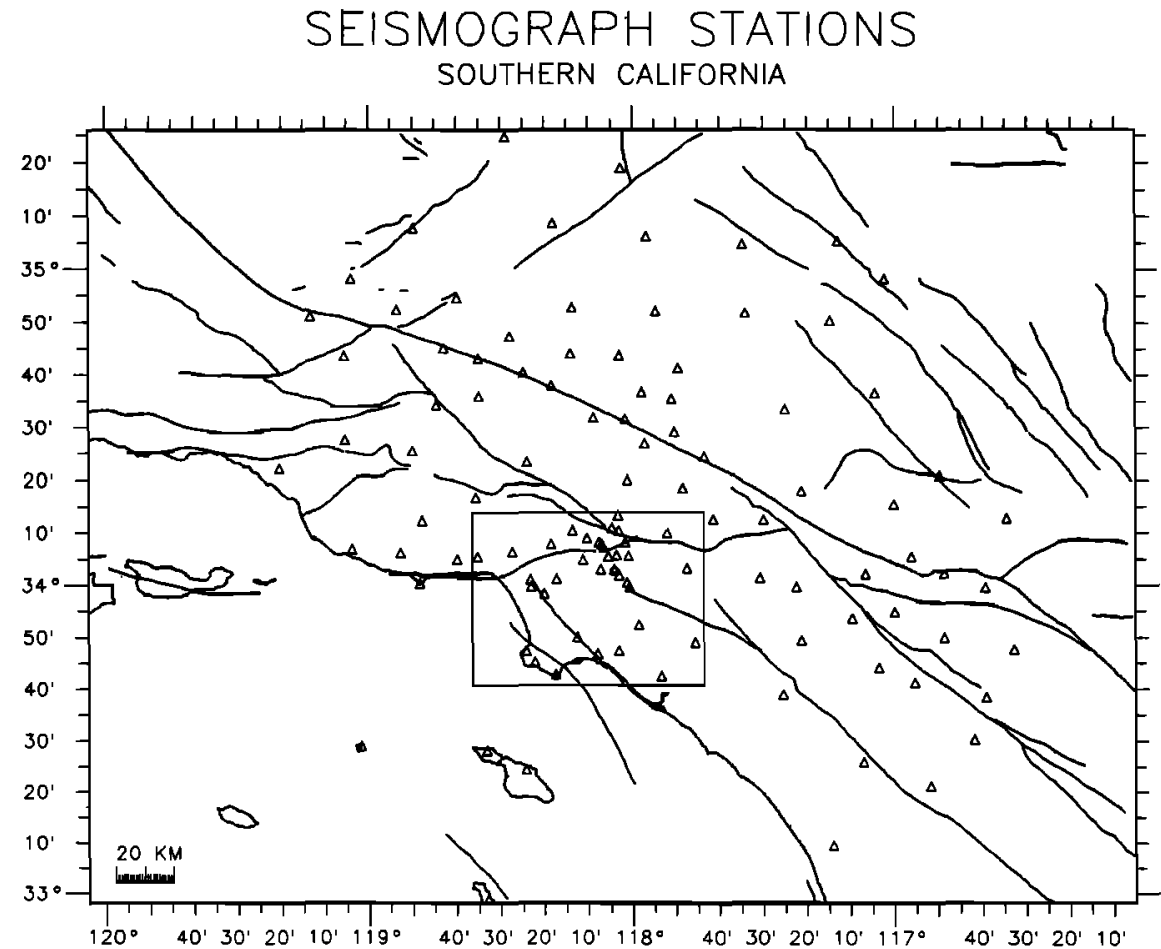

\section{SEISMOGRAPH STATIONS \\ LOS ANGELES BASIN}

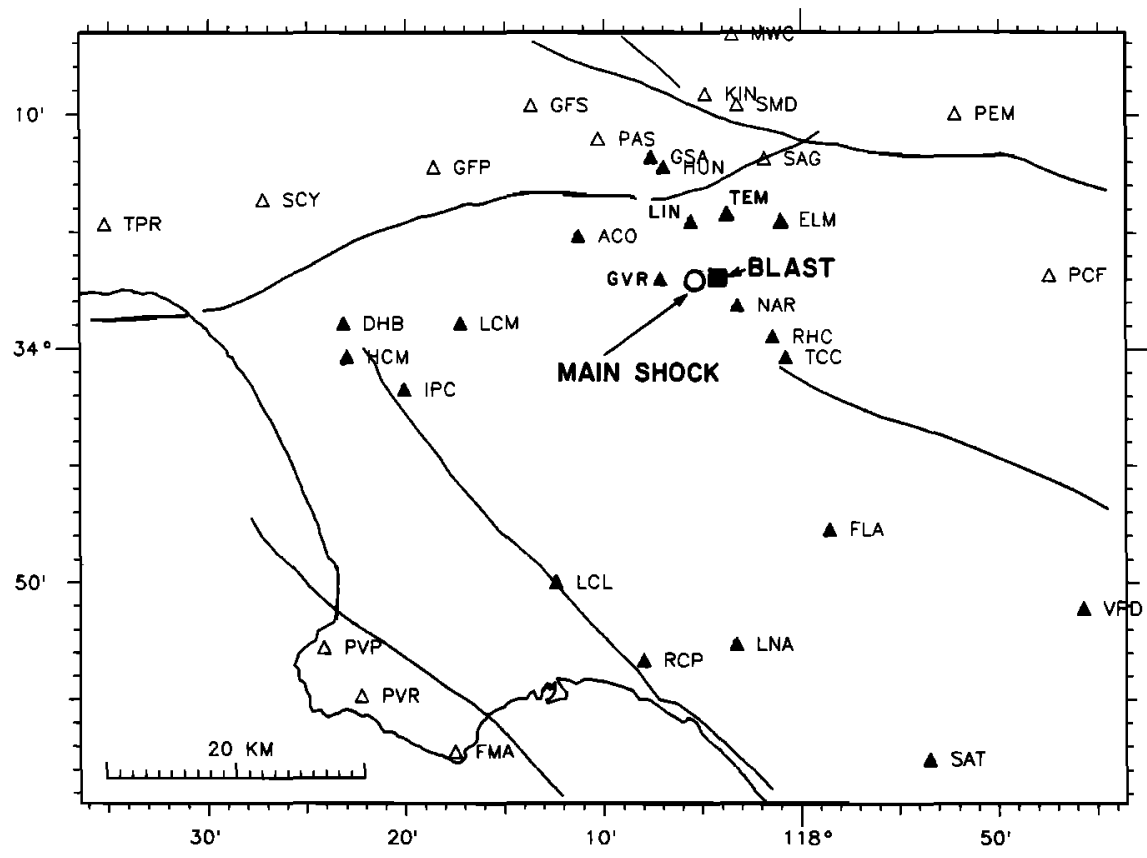

Fig. 3. (Top) USC and CIT/USGS seismic network stations that provided arrival time data for the velocity inversion. (Bottom) Locations of the mainshock (open circle), the calibration blast (solid square), and the nearby stations. Open and solid triangles are stations that were assigned southern California and Los Angeles basin velocity model, respectively (see Table 1).

Some of the aftershocks were also recorded by portable instruments including the USGS GEOS recorders [Borcherdt et al., 1985], USGS 5-day recorders, and USGS DR200 recorders. These instruments were deployed in the field 36-72 hours following the occurrence of the mainshock. The GEOS data (P. Spudich written communication, 1988) included in this study cover the time period October 3-7. The data from the 5-day 


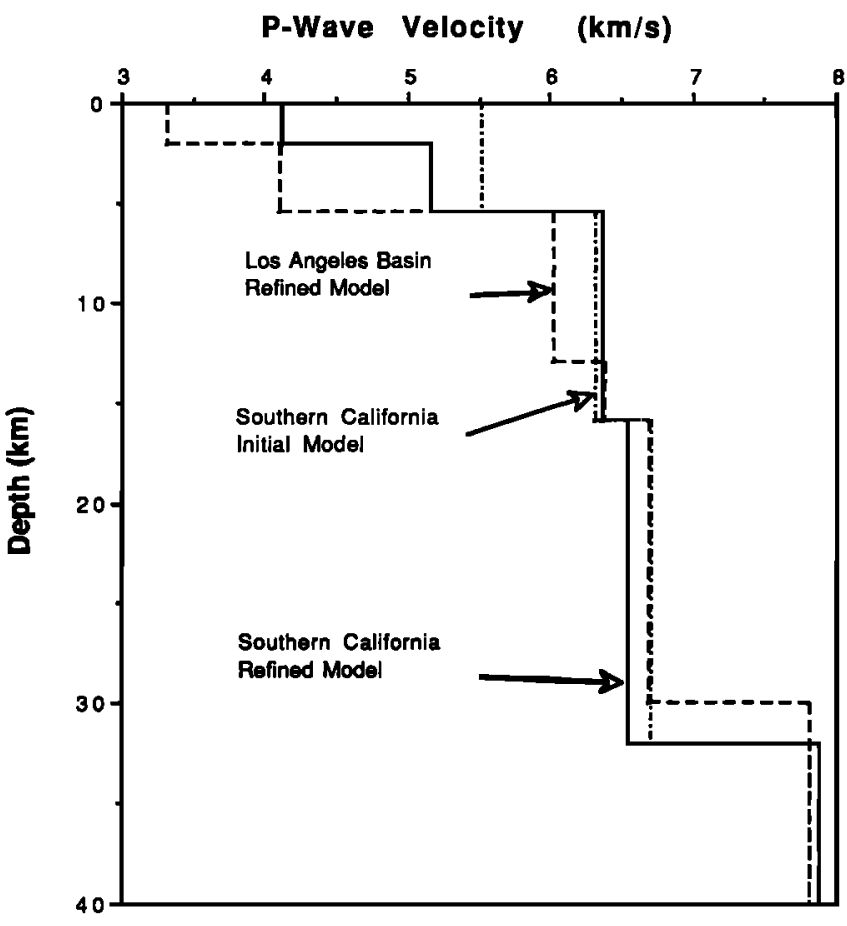

Fig. 4. The initial and refined velocity models for southem California and refined velocity model for the Los Angeles basin obtained from the VELEST inversion.

recorders (A. Michael, written communication, 1987) were played back through a real time processor (RTP [Allen, 1982] and cover the time period October 4-15. The DR200 recorders (C. Bufe, written communication, 1988) provided additional data for the $\mathrm{M}>2.5$ aftershocks from October 3-10.

On November 8, 1987, a calibration blast was detonated near the Whittier Narrows, within a few kilometers of the epicenter of the mainshock (Figure 3). It was recorded to distances of $100 \mathrm{~km}$ by both seismic networks and portable instruments deployed at sites previously occupied for recording of aftershocks [Perkins, 1988]. This blast provided the necessary arrival time data needed to constrain the velocities of the top layers in the velocity models.

\section{VELOCITY MODEL}

The arrival time data from the Whittier Narrows sequence and the calibration blast have been used to determine the crustal velocity structure of the Los Angeles basin and the surrounding areas. A data set of 190 earthquakes, where each earthquake had between 20 and $104 P$ and $S$ arrival times recorded by as many as 90 stations (Figure 3), was selected for simultaneous inversion. The VELEST method [Roecker and Ellsworth, 1978] was used to invert these data and the blast data to obtain two velocity models, a set of station delays, and hypocenters. To obtain velocity models that correspond to the local geology, seismic stations located in the Los Angeles basin were assigned a separate initial velocity model with surface layers of low velocities appropriate to the sediments in the basin (Figure 4 and Table 1). Stations located outside the basin were assigned an initial velocity model derived by Hadley and Kanamori [1977] for southern California; the top layer was divided into two separate layers to better model near-surface velocity variations (Figure 4). The final velocity models and station delays were used with the location algorithm HYPOINVERSE [Klein, 1985] to relocate the mainshock and its aftershocks.

To show how the blast arrival time data are fitted by the routine velocity model, the observed travel times from the blast are plotted in a reduced travel time graph (Figure 5a). The corresponding calculated travel time curve from the routine velocity model is also shown. The observed travel times show some scatter and average $0.77 \mathrm{~s}$ larger than the calculated travel times. The fit of the arrival times of the blast to the final models is shown in Figure $5 b$, where the observed travel times have been corrected using the corresponding station delays. The solid circles that represent travel times to basin stations are fitted with the basin model, while the open circles that represent travel times to stations located outside the basin are fitted with the southern California model (see also Figure 3). To account for the delay associated with the downward traveling rays at the blast site, the blast was assigned a delay of the same size as the closest station delay. This delay of $0.16 \mathrm{~s}$ was subtracted before plotting the calculated travel times in Figure $5 b$. The top low-velocity layers in the models for the basin, as well as outside the basin, remove the bias of $0.61 \mathrm{~s}$ while the blast delay accounts for $0.16 \mathrm{~s}$. The reduction in the scatter of observed travel times is accomplished by including the station delays.

Because most of the hypocenters are located deeper than $10 \mathrm{~km}$ the VELEST method may smooth the velocities of the upper layers such that the velocity of the surface layer may be set too high and the velocities of the layers between the surface and the shallowest hypocenters too low. To minimize this smoothing effect, the velocity of the top layer in the basin model was kept fixed during the first six iterations. The VELEST inversion converged usually after 12 iterations. The models and set of station delays presented here are preferred because they reduced the

TABLE 1. $P$ Wave Velocity Models

\begin{tabular}{lcc}
$\begin{array}{l}\text { Initial } \\
\text { Velocity, } \\
\mathrm{km} / \mathrm{s}\end{array}$ & $\begin{array}{c}\text { Refined } \\
\text { Velocity, } \\
\mathrm{km} / \mathrm{s}\end{array}$ & $\begin{array}{c}\text { Depth to Top } \\
\text { of Layer, } \\
\mathrm{km}\end{array}$ \\
\hline \multicolumn{3}{c}{ Southern California Model } \\
5.50 & 4.10 & 0.00 \\
5.50 & 5.16 & 2.00 \\
6.30 & 6.35 & 5.50 \\
6.70 & 6.54 & 16.0 \\
7.80 & 7.87 & 32.0 \\
& & \\
3.30 & Los Angeles Basin Model \\
4.00 & 3.31 & 0.00 \\
5.90 & 4.08 & 2.00 \\
6.50 & 6.02 & 5.50 \\
6.70 & 6.37 & 13.0 \\
7.80 & 6.68 & 16.0 \\
& 7.87 & 30.0 \\
\hline
\end{tabular}


WHITTIER NARROWS BLAST DATA
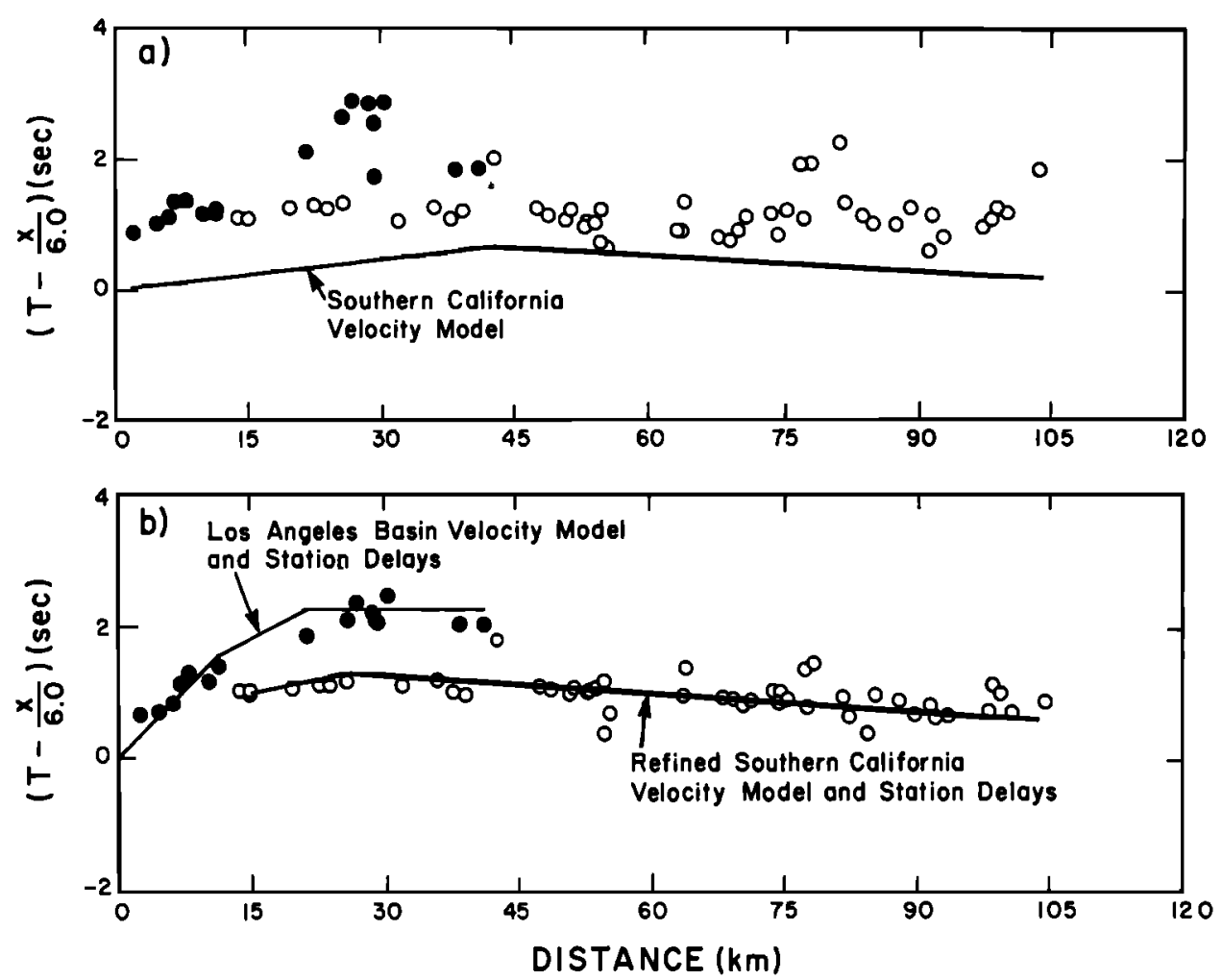

Fig. 5. (a) The arrival time data from the Whittier Narrows calibration blast of November 8, 1987, plotted as reduced travel time with reduction velocity of $6 \mathrm{~km} / \mathrm{s}$ versus distance. Data from stations in the Los Angeles basin are shown as solid circles. Also shown as a solid line are the corresponding reduced travel times through the initial southem California velocity model (Table 1). (b) The observed travel time data are divided into two groups and fit with two refined models and corresponding sets of station delays. The Los Angeles basin model includes only arrival times recorded by stations in the basin (see Figure 3). The refined southern California model includes only stations located outside the basin.

average root-mean-square (Rms) from 0.23 to $0.09 \mathrm{~s}$ and provided the smallest Rms for the set of 190 earthquakes. Furthermore, when these models and station delays are used to locate the blast assuming an unknown origin time and location, the blast is located $0.5 \mathrm{~km}$ to the westnorthwest of the true location at a depth of $0.4 \mathrm{~km}$ with a source delay of $0.24 \mathrm{~s}$.

The mislocation vectors between hypocenters obtained from using the routine velocity models and no station delays and hypocenters obtained using the two new models and the corresponding set of delays are shown in Figure 6. Only four events (the mainshock, $M_{L}=5.3$ aftershock, a $M_{L}=4.7$ aftershock, and the calibration blast) are included for clarity. The calibration blast has three locations that are the true location, routine location, and final location (Table 2). The mislocation vectors for the blast represent a maximum estimate, and corresponding mislocation vectors for earthquake hypocenters should in all cases be smaller, because the rays traveling away from the blast pass twice through the near-surface heterogeneous velocity structure. The final mislocation of the blast may in part be caused by the seismic network geometry with many stations located to the north and west. The mislocation vectors of the mainshock and the two largest aftershocks show a systematic displacement to the south, and the focal depths change significantly when using the new model and delays. In particular, the new models and delays locate the mainshock within the aftershock zone. The routine model does a poorer job of locating the mainshock and puts it at a shallower depth than most of the aftershocks. Because the new models and delays are consistent with the geological contrast between the Los Angeles basin and the adjacent mountain ranges, they provide more consistent relative hypocenters. The $0.5 \mathrm{~km}$ mislocation of the blast is indicative of the hypocenter reliability.

A new layer boundary was added at $13 \mathrm{~km}$ depth in the Los Angeles basin model to account for possible gradual increase in $P$ wave velocity with depth. The boundary at $13.0 \mathrm{~km}$ depth appears to be significant, and the results of the inversions show consistently higher velocities beneath the boundary than above it. The effect on earthquake locations was tested by varying the layer boindaries and repeating the inversion. In most cases the focal depths did not depend strongly on the choice of layer boundaries. For instance, moving the $16 \mathrm{~km}$ deep layer boundary down to $18 \mathrm{~km}$ changed the focal depths of the earthquakes by less than $0.5 \mathrm{~km}$. Because the inversion adjusts the velocities within each layer, there is an obvious trade-off between velocities and layer structure. In general, the two final models give lower Rms values for the improved hypocenters than other models tried in the test inversions.

The final southern California model is similar to the 

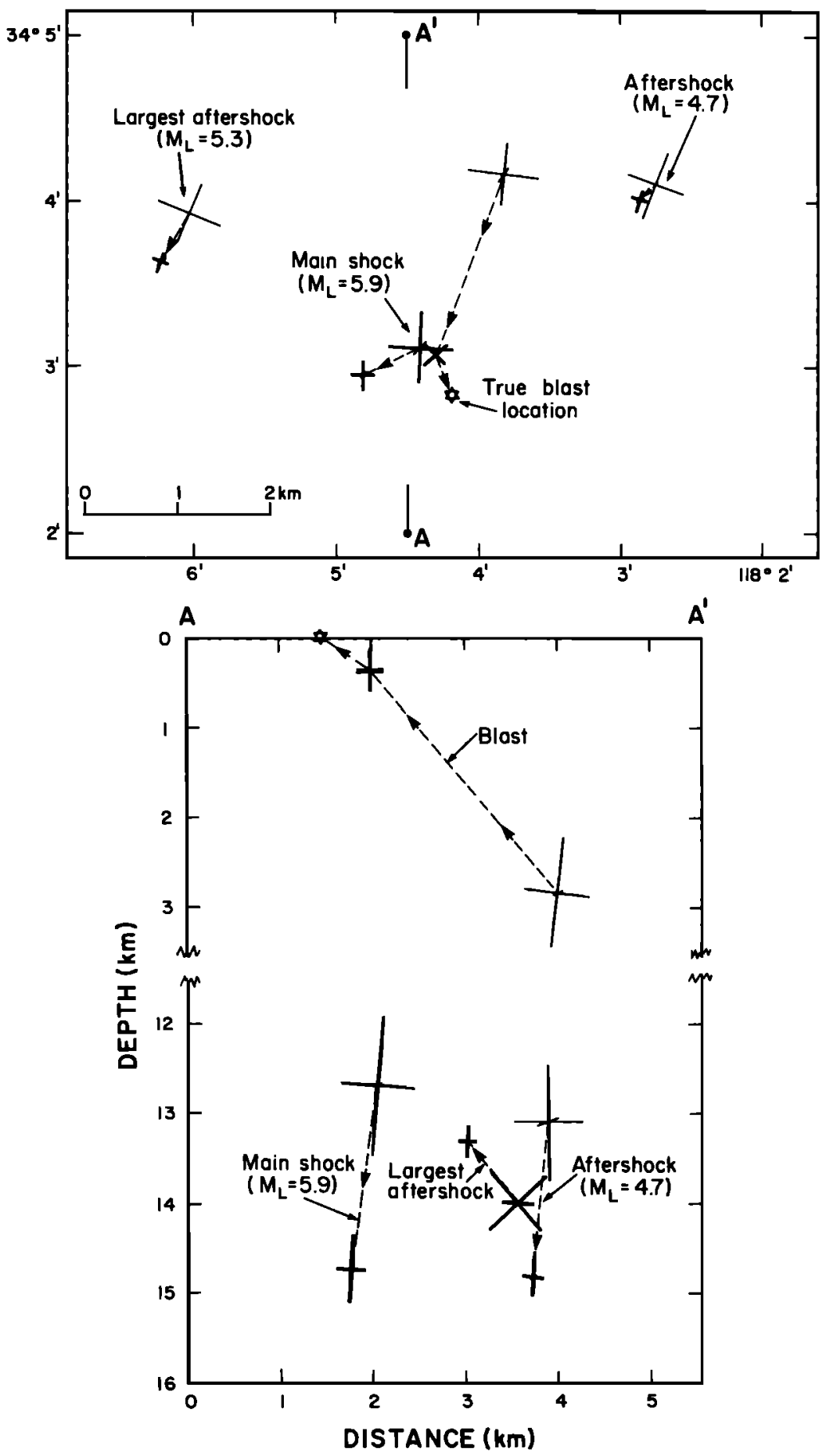

Fig. 6. Hypocenters of the mainshock, two aftershocks, and the calibration blast. Hypocenters obtained from HYPOINVERSE using the initial southern California model have larger error bars and are drawn with thin lines. Corresponding hypocenters obtained with the refined velocity models and station delays have smaller error bars and are drawn with thick lines. The error bars are the axes of the error ellipsoid calculated by HYPOINVERSE. The true location of the blast is shown by a star (see also Table 2).

model used for calculating routine earthquake locations except for the new surface low-velocity layer (Figure 4). The Los Angeles basin model has lower near-surface velocities than the southern California model and an additional boundary at $13 \mathrm{~km}$ depth. The velocities in the Los Angeles basin are significantly lower to depths of 13 $\mathrm{km}$, indicating that the velocities of the basement rocks below the basin sediments appear to be similar in magnitude to the basement velocities observed at the surface outside the basin. This model differs from the model derived by Hauksson et al. [1988] in that the top $5.5 \mathrm{~km}$ of this model has lower velocities and the depth range $5.5-16 \mathrm{~km}$ has slightly higher velocities. The error bars are small, and the velocities are well resolved because 
TABLE 2. Whittier Narrows Calibration Blast of 1210:10.01, November 8, 1987

\begin{tabular}{|c|c|c|c|c|c|c|c|c|c|}
\hline & Iter & $\begin{array}{c}\text { Latitude } \\
\mathbf{N}\end{array}$ & $\begin{array}{l}\text { Longitude } \\
\text { W }\end{array}$ & $\begin{array}{l}\text { Depth, } \\
\text { km }\end{array}$ & $\begin{array}{l}\text { Del, } \\
\text { km }\end{array}$ & $\begin{array}{c}\text { Arms, } \\
\mathrm{s}\end{array}$ & $\begin{array}{l}\text { rms, } \\
\text { s }\end{array}$ & $\begin{array}{c}\text { Erh, } \\
\mathrm{km}\end{array}$ & $\begin{array}{l}\text { Erz } \\
\mathbf{k m}\end{array}$ \\
\hline \multicolumn{10}{|c|}{$\begin{array}{l}\text { Routine veleocity } \\
\text { model }\end{array}$} \\
\hline True location & & $34^{\circ} 2.84^{\prime}$ & $118^{\circ} 4.19^{\prime}$ & 0.00 & 0.00 & 0.77 & 0.80 & & \\
\hline Final location & 6 & $34^{\circ} 4.16^{\prime}$ & $118^{\circ} 3.82^{\prime}$ & 2.84 & 2.50 & 1.10 & 0.37 & 0.4 & 0.6 \\
\hline \multicolumn{10}{|c|}{$\begin{array}{l}\text { New models and } \\
\text { delays }\end{array}$} \\
\hline True location & & $34^{\circ} 2.84^{\prime}$ & $118^{\circ} 4.19^{\prime}$ & 0.00 & 0.00 & 0.16 & 0.24 & & \\
\hline Final location & 4 & $34^{\circ} 3.07^{\prime}$ & $118^{\circ} 4.30^{\prime}$ & 0.37 & 0.50 & 0.24 & 0.18 & 0.2 & 0.2 \\
\hline
\end{tabular}

Iter, number of iterations calculated by HYPOINVERSE; depth, calculated depth of blast in kilometers; Del, distance in kilometers between true and calculated location; Arms, average root-mean-square residual of observed and calculated travel time in seconds; rms, normalized root-mean-square residual; Erh, horizontal error in kilometers; Erz, depth error in kilometers.

many rays pass through each layer. Refined earthquake hypocenters and focal mechanisms have been calculated using the new crustal velocity models and the corresponding station delays.

\section{AFTERSHOCK STATISTICS}

The Whittier Narrows earthquake was followed by an unusually small number of aftershocks. The number and temporal distribution of aftershocks in a sequence can be described by the modified Omori's law:

$$
N(t)=K \cdot(t+C)^{-p}
$$

where $N$ is the number of earthquakes per time interval, $t$ is time since the mainshock, and $K, C$, and $p$ are constants [e.g., $U t s u, 1971$ ]. $K$ is the number of events in the first hour, $p$ represents how quickly the sequence decays, and $C$ is related to incompleteness of recording immediately following the mainshock. The fit to the modified Omori's law was recently determined for $70 M \geq 5$ California aftershock sequences [Reasenberg and Jones, 1989] assuming a constant $\mathrm{C}=0.05$ day. Only aftershocks within three units of magnitude of the mainshock (i.e., $2.9 \leq M<5.9$ for Whittier Narrows) were used to determine $K$. This constant $K$ is referred to as $K_{3}$ because it uses only a range of three units of magnitude, which makes it possible to compare sequences with different mainshock magnitude. Thus the constant $K_{3}$ is independent of the magnitude of the mainshock and represents real variations of aftershock activity.

In California, $K_{3}$ has ranged from 1.9 to 115 ; the $K_{3}=4.0$ value for Whittier Narrows is among the lowest.
The $p$ value for Whittier Narrows of 1.51 is the third highest in the California range from 0.5 to 2.0 . A comparison with other Los Angeles area aftershock sequences is shown in Table 3. With a low $K_{3}$ (number in the first hour) and high $p$ or fast decay rate, Whittier Narrows had the smallest number of aftershocks for its magnitude of any Los Angeles earthquake.

What aftershocks did occur, however, tended to be large. In the Gutenberg-Richter relation

$$
N(M)=10^{a-b M}
$$

the $b$ value was $0.67 \pm .05$ from a maximum likelihood determination. This is in the lowest $10 \%$ of California aftershock sequences which range from 0.5 to 1.4 [Reasenberg and Jones, 1989]. Thus, although the overall rate of aftershock activity is low, the occurrence of two large aftershocks $(M=5.3$ on October 4 and $M=4.7$ on February 11) fits the magnitude distribution predicted from smaller events (Figure 7).

Because of the low $b$ value, the cumulative seismic moment released in the aftershock sequence was not low even though the number of aftershocks was small. The ratio of the cumulative aftershock seismic moment divided by the seismic moment of the mainshock has been calculated for 70 sequences in southern California (moments estimated from the magnitudes). The seismic moment release in these aftershock sequences ranged from $0.2 \%$ to $150 \%$ of the moment of the mainshock, with a mean of $8 \%$. The Whittier Narrows aftershock sequence was close to an average sequence with a cumulative seismic moment of $12.8 \%$ of the mainshock moment.

TABLE 3. Aftershock Statistics for Los Angeles Basin Earthquakes

\begin{tabular}{llccrcc}
\hline Earthquake & Date & Mag & Depth, km & \multicolumn{1}{c}{$K_{3}$} & $P$ & $b$ \\
\hline Long Beach & March 11, 1933 & 6.3 & $\sim 10$ & 115.0 & 1.37 & $1.00 \pm 0.08$ \\
San Fernando & Feb. 9, 1971 & 6.6 & $8 \pm 4$ & 11.3 & 1.24 & $1.04 \pm 0.08$ \\
Point Mugu & Feb. 21, 1973 & 5.5 & 17 & 2.5 & 0.75 & $0.57 \pm 0.12$ \\
Malibu & Jan. 1, 1979 & 5.0 & 12 & 19.6 & 1.17 & $0.87 \pm 0.07$ \\
Whittier Narrows & Oct. 1, 1987 & 5.9 & 15 & 4.0 & 1.51 & $0.67 \pm 0.05$ \\
\hline
\end{tabular}



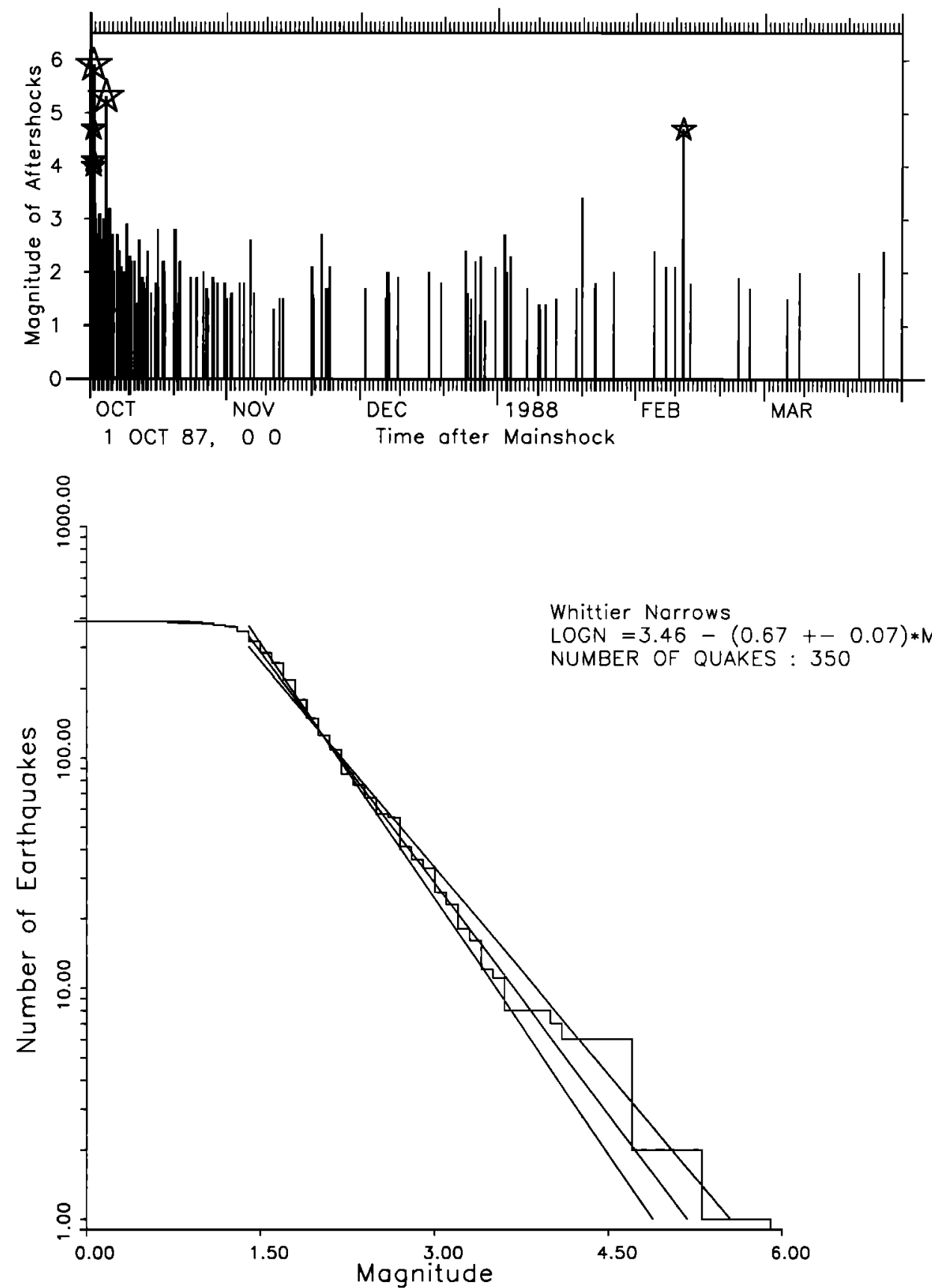

Fig. 7. (Top) A bar graph of magnitude versus time for the Whittier Narrows sequence. Events of $M_{L} \geq 4.5$ are highlighted with a star symbol. (Bottom) Cumulative number of events versus magnitude in the Whittier Narrows sequence. The maximum likelihood fit lines represent mean, maximum, and minimum $b$ values.

However, the moment release was accomplished through a very small number of large aftershocks.

Hauksson and Jones [1988] suggested that high stress drop mainshocks with a clean rupture often had a rapidly decaying aftershock sequence, while low stress drop events, with an incomplete rupture, were more likely to have prolonged aftershock sequences. The Whittier Narrows earthquake sequence fits this pattern with a relatively high stress drop as compared to most other southern California mainshocks [Bent and Helmberger, this issue] and small number of aftershocks. Low $b$ values have been associated with high confining stress [e.g., Scholz, 1968]. However, the physical meaning of the parameters $K_{3}, p$, and $b$ has yet to be fully understood. The main use of determining $K_{3}, p$, and $b$ is to describe the statistical properties of each sequence in a quantitative way. These parameters can in turn be used to predict the development of ongoing sequences near real-time for mitigation of earthquake hazards [Reasenberg and Jones, 1989].

\section{EARTHQUAKE LOCATIONS}

The epicenter of the mainshock was located at $34^{\circ} 2.96 ' \mathrm{~N}, 118^{\circ} 4.86^{\prime} \mathrm{W}$, at a depth of $14.6 \mathrm{~km}, 3 \mathrm{~km}$ north of the Whittier Narrows (Figure 1). The calculated relative uncertainties in the epicenter determination from 

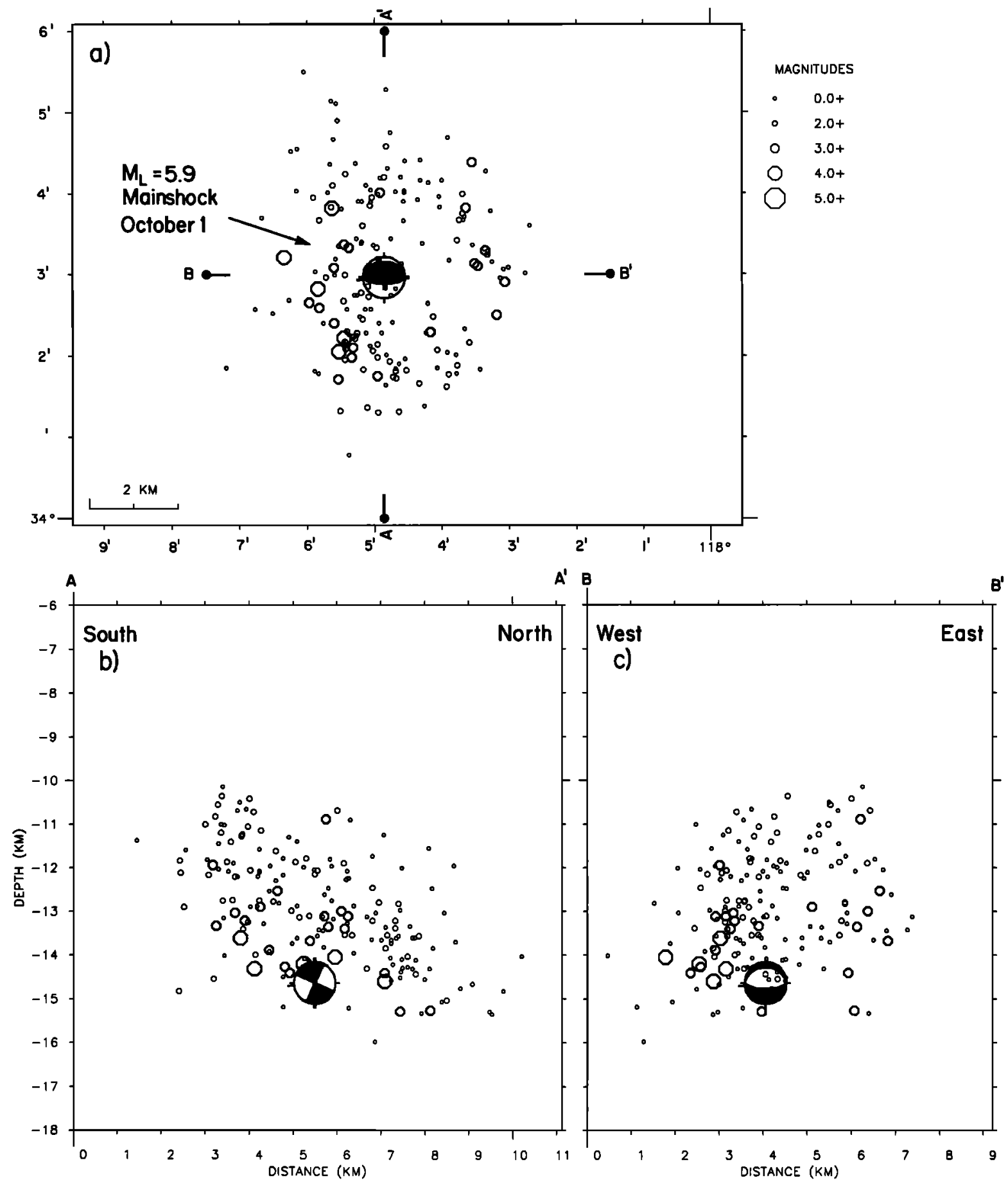

Fig. 8. (a) Map , (b) south-north cross section, and (c) front view from the south of the mainshock focal mechanism and the following aftershocks until 10:58, October 4, 1987, which was the time of the largest aftershock. Lower hemisphere focal mechanism from first motion polarities, where compressive quadrants are black and dilatational quadrants are white, is shown for the mainshock. Only hypocenters with location and depth errors Erh $\leq 1.0 \mathrm{~km}$ and Erz $\leq 1.0 \mathrm{~km}$ as determined by HYPOINVERSE are plotted.

HYPOINVERSE are $0.2 \mathrm{~km}$, and the absolute location bias of the calibration blast indicates that the absolute error is less than $0.5 \mathrm{~km}$. The epicenter is located $5-10$ $\mathrm{km}$ to the northwest of the terminus of the mapped surface expression of the Whittier fault. The relative error of the depth of focus of the mainshock is less than $0.4 \mathrm{~km}$, and the absolute error may also be less than $0.5 \mathrm{~km}$, similar to the absolute location errors of the blast.
The aftershocks form two spatial groups, one associated with the mainshock rupture plane and a second associated with the largest $\left(M_{L}=5.3\right)$ aftershock. In map view the first group forms an annulus centered at the epicenter of the mainshock with a diameter of $4-6 \mathrm{~km}$ (Figure 8). In a north-south cross section, the aftershocks that occurred during the first three days (before the largest aftershock) suggest a surface dipping gently to the north. 
Both the north-south and the east-west cross sections show that most of the aftershocks are located within or above the mainshock fault plane. Thus it appears that the mainshock resulted from slip on a plane striking west and dipping $25^{\circ}$ to the north.

The largest aftershock $\left(M_{L}=5.3\right)$, which occurred at 1059 UT October 4, 1987, was located $2 \mathrm{~km}$ to the northwest of the mainshock's epicenter (Figure 9). The focus of the largest aftershock is located at a depth of 13.3 $\mathrm{km}$ within the hanging wall of the thrust sheet, $1.5 \mathrm{~km}$ shallower than the rupture surface of the mainshock. The locations of the largest aftershock and its own aftershocks define a north-northwest striking, steeply dipping fault (Figure 9). This fault forms the western edge of the aftershock distribution of the mainshock (Figure 8). The spatial distribution of aftershock hypocenters indicates that this steeply dipping fault exists only within the hanging wall. The stress loading from the mainshock appears to have triggered the largest aftershock on this steeply dipping fault.

The mainshock and aftershocks from October 1, 1987, to March 31, 1988, are shown in Figure 10. Most of the aftershocks, including the two largest aftershocks, are located to the west of the mainshock's epicenter near the aftershock zone of the largest aftershock of October 4, 1987. Hence the fault that caused the largest aftershock also may have caused many of the aftershocks that occurred during October 1-4, 1987. A comparison of Figures 8, 9, and 10 illustrates how the spatial distribution of aftershocks develops with time, from October 1987 to March 1988. For instance, most of the late aftershocks are located to the south and west of the mainshock's epicenter.

Two features of the spatial distribution of the earthquake sequence are unusual. First, the aftershocks are unusually deep and never approach the surface; the shallowest aftershock is $10 \mathrm{~km}$ deep. Furthermore, no surface rupture for the Whittier Narrows earthquake has been documented [Hauksson et al., 1988]. This is further evidence that the sequence is related to a buried or a blind thrust fault that does not extend to the surface. Many earthquakes of this magnitude that have occurred in California since 1930 on strike-slip or reverse faults show fault rupture and aftershocks that extend to shallower depths and often produce measurable offset at the surface. Second, the areal extent of the aftershock zone is small. By comparison, the 1986 North Palm Springs earthquake $\left(M_{L}=5.6\right.$ and $M_{0}=1 \times 10^{25}$ dyn $\mathrm{cm}$ ) also occurred on a dipping fault and had an aftershock zone of $16 \mathrm{~km}$ by 9 $\mathrm{km}$ [Jones et al., 1986] and thus an aftershock area over 6 times larger than that of the Whittier Narrows earthquake. If the aftershock zone corresponds to the fault rupture surface, this suggests that the Whittier Narrows mainshock had a high stress drop [Lin and Stein, this issue] and perhaps a long recurrence interval. Scholz et al. [1986] and Kanamori and Allen [1987] have shown that earthquakes with longer repeat times have higher stress drops on the average, possibly caused by increased strength with longer healing time-for the fault.

\section{Focal MECHanisms}

The $\mathbf{P}$ first motion polarities were used to determine single-event lower hemisphere focal mechanisms for the mainshock and 58 aftershocks of $M_{L} \geq 2.2$ (Figure 11 and Table 4). Single-event focal mechanisms were attempted for all $M_{L} \geq 2.5$ events and some $M_{L} \geq 2.2$ events. The grid searching algorithm by Reasenberg and Oppenheimer [1985] was used to determine the nodal planes. The original seismograms were rechecked to correct possible mistakes in determining first motions and to include all important first motions. Of the 59 events, only two had multiple possible focal mechanism solutions. In most cases the nodal planes are well constrained and errors in strike, dip, and rake are usually less than $5^{\circ}$.

The nodal planes in the focal mechanism of the mainshock strike within $5^{\circ}$ of due west and dip $25^{\circ} \pm 5^{\circ}$ to the north and $65^{\circ} \pm 5^{\circ}$ to the south, respectively (Figure 12). The spatial distribution of the hypocenters of the mainshock and its aftershocks, as well as the focal mechanism of the mainshock, indicate that the causative fault is the $25^{\circ}$ north dipping thrust fault striking west and located at depths from 10 to $16 \mathrm{~km}$ (Figure 8). The slip on this inferred fault was pure thrust with north over south movement. Both the strike and dip of the mainshock fault differ significantly from the mapped strike and dip of the Whittier fault [Yerkes et al., 1965]. In addition, the relative locations of the mainshock's hypocenter and the projected location of the Whittier fault do not coincide. Thus the earthquake did not occur on the Whittier fault.

The single-event lower hemisphere focal mechanisms of the mainshock and 59 aftershocks are shown in Figure 10 and are listed in Table 4 . The focal mechanisms are plotted at their respective epicenter in Figure 12 along with approximate outlines of the two aftershock zones. These focal mechanisms document a complex history of faulting. Numerous aftershocks with similar focal mechanisms as the mainshock occurred in and around the outer edges of the proposed rupture area. Within $30 \mathrm{~min}$ of the mainshock, a north-south trending sequence of events occurred 1-2 km to the west of the mainshock hypocenter and at similar depths. These events showed reverse faulting on north striking and almost vertical (or slightly west dipping) planes. The largest aftershock $\left(M_{L}=5.3\right)$ occurred on October $4,2 \mathrm{~km}$ northwest of the mainshock epicenter. This aftershock showed mostly right-lateral faulting on a north-northwest striking plane dipping steeply to the west. It was also followed by its own aftershock sequence that clearly identified the northnorthwest striking nodal plane as the rupture surface (Figure 9). The inferred rupture surface of the largest aftershock is shown in Figure 12 as a dipping plane in the depth range from $13.5 \mathrm{~km}$ up to $9.0 \mathrm{~km}$. The aftershock sequence decayed rapidly following the largest aftershock. The complexities of faulting in the aftershock sequence are also illustrated by at least two possible left-lateral strikeslip focal mechanisms showing motion on steeply dipping north striking faults, which can be identified near the eastern edge of the mainshock rupture surface. Similarly, several right-lateral strike-slip mechanisms are observed on the west side of the mainshock rupture. Furthermore, three small events show normal faulting along northwest striking faults at the southern end of the mainshock rupture zone at similar depths $(12-13 \mathrm{~km})$ as other earthquakes at that location. 

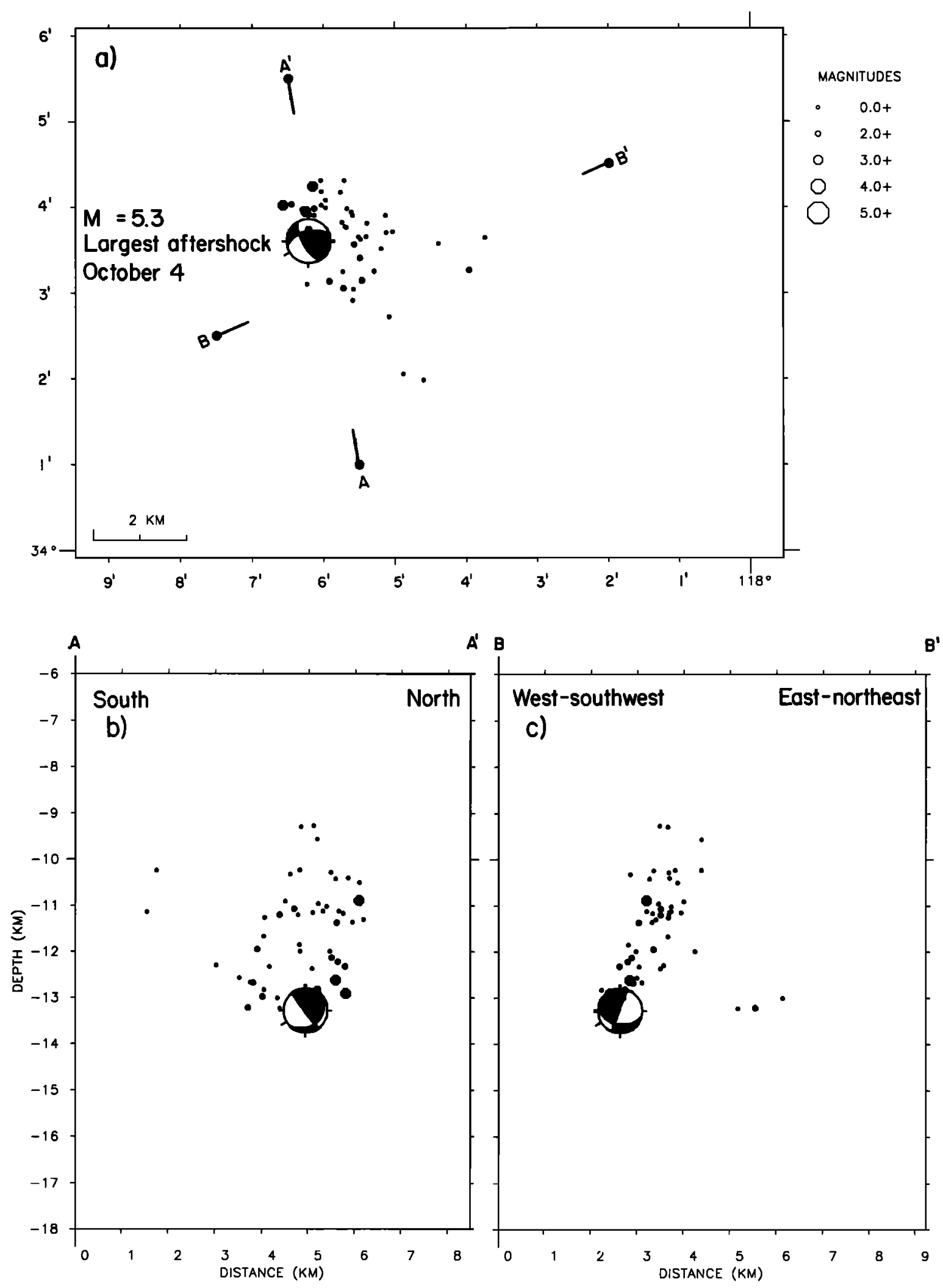

Fig. 9. (a) Map, (b) south-north cross section projected onto a north-south line, and (c) cross section projected onto a west-southwest - east-northeast line of the focal mechanism of the largest aftershock and the aftershocks that followed during the next 24 hours. Lower hemisphere focal mechanism from first motion polarities, where compressive quadrants are black and dilatational quadrants are white, is shown for the largest aftershock. Only hypocenters with location and depth errors Erh $\leq 1.0 \mathrm{~km}$ and Erz $\leq 1.0 \mathrm{~km}$ as determined by HYPOINVERSE are plotted. 


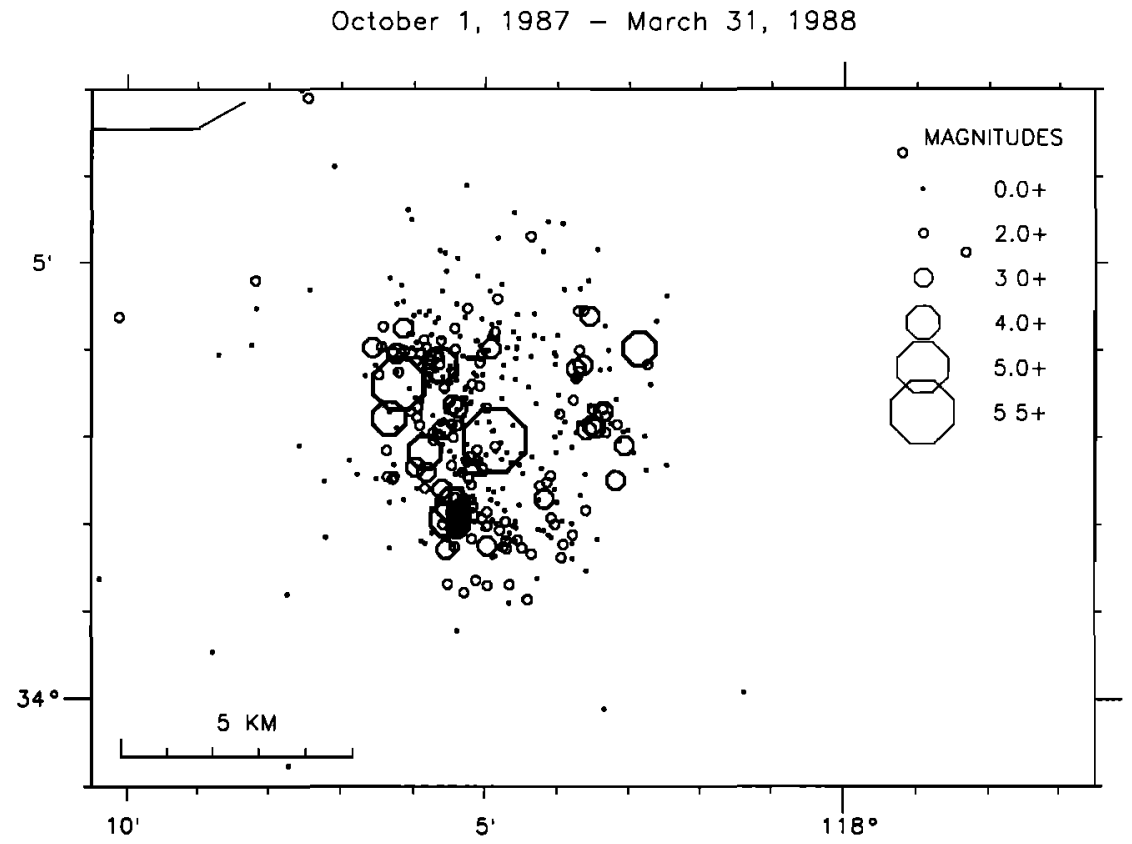

Fig. 10. Map of the mainshock and aftershocks from October 1, 1987 to March 31, 1988, showing the concentration of aftershocks on the west side of the mainshock epicenter.

In general, most of the aftershocks are consistent with deformation of the hanging wall induced by the thrust faulting observed in the mainshock. The right-lateral strike-slip aftershocks on the west side, in conjunction with similar left-lateral events on the east side of the mainshock rupture, could result from movement of the hanging wall to the south as it readjusts to the new crustal stress field following the mainshock. Several earthquakes with mechanisms similar to the mainshock are located to the north of the mainshock, but at depths of $10-11 \mathrm{~km}, 5$ $\mathrm{km}$ above the assumed rupture surface of the mainshock (Figure 13). These focal mechanisms are predicted by some models of ramp faulting to accommodate bending of the hanging wall [J. Suppe, personal communication, 1988).

The intersection of the mainshock and aftershock fault planes can be seen in the stereoscopic projection in Figure 13. The gently dipping mainshock fault plane is bounded on the west by the steeply dipping fault. This vertical fault is confined to the hanging wall of the mainshock fault. This again suggests that the vertical fault is accommodating deformation of the hanging wall. A stress inversion of these focal mechanism data yields a stress field with the least principal stress vertical and the maximum principal stress oriented approximately northsouth (A. J. Michael, Stress analysis of the Whittier Narrows, California, aftershock sequence, submitted to Journal Geophysical Research, 1988).

Several minor faults have been mapped during oil exploration or are inferred from geologic mapping and are located between the Whittier Narrows and the San Rafael Hills, cutting across the aftershock zone (Figure 14). Most of these northwest striking faults have both dip-slip and strike-slip offsets of at most a few kilometers [Lamar, 1970]. None of these faults have the correct dip or strike to accommodate the mainshock. Furthermore, because they strike northwest and are right-lateral, they seem to be unlikely to accommodate the north to north-northwest motion on the west side of the aftershock zone or the leftlateral motion on north to northeast striking faults to the east. Hence it is possible that these faults do not extend to depths of 10-16 km where the Whittier Narrows sequence took place. Alternatively, these faults are no longer active, and a different set of unmapped faults is currently accommodating the ongoing crustal deformation.

The complexity of the focal mechanisms in the aftershock sequence illustrates that down to depths of 10$16 \mathrm{~km}$, fault structures such as north striking reverse faults, right-lateral strike-slip faults striking north to northwest, left-lateral strike-slip faults striking north to northeast, and normal faults striking north to northwest, are all seismogenic in the Los Angeles basin. These seismogenic structures all exist in addition to the west striking thrust fault that caused the mainshock. Hence to understand the seismogenic potential of these structures, systematic mapping of the relative spatial extent of primary structures and secondary structures that may play a segmentation role is needed.

\section{Discussion}

The 1987 Whittier Narrows mainshock is the largest earthquake to occur in southern California west of the San Andreas fault since the 1971 San Fernando earthquake. Although both of these earthquake sequences occurred in similar tectonic environments, there are remarkable differences between the two mainshocks and similarities between their respective aftershock sequences.

The San Fernando earthquake had a 15 times larger seismic moment [Heaton and Helmberger, 1979] and a 15 km long surface rupture [Whitcomb et al., 1973], while the Whittier Narrows earthquake did not rupture the surface. The difference in the mainshock focal 


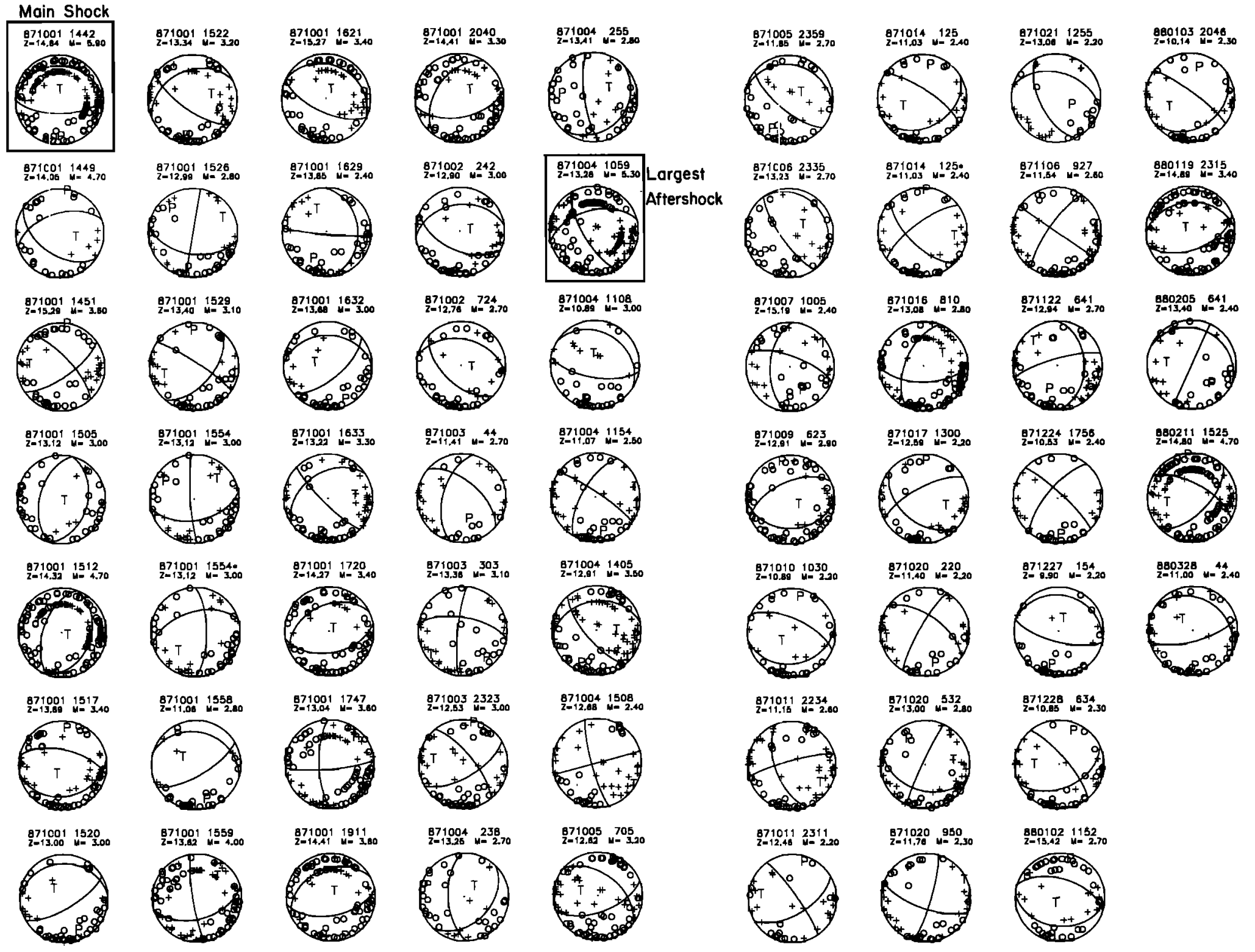

Fig. 11. Lower hemisphere, single-event focal mechanisms for the Whittier Narrows mainshock and 58 aftershocks. Pluses indicate compressional $P$ first motion polarities, while open circles indicate dilational $P$ first motion polarities. Each mechanisms is labeled with date and hour/minute of origin time. $Z$ is the depth in kilometers, and $M$ is the local magnitude. Nodal planes were determined using the Reasenberg and Oppenheimer [1985] grid searching algorithms. The second solutions for the two events with multiple solutions identified by the algorithm are flagged by a star. 
TABLE 4. Locations and Fault Plane Solutions of the Whittier Narrows Aftershock Sequence

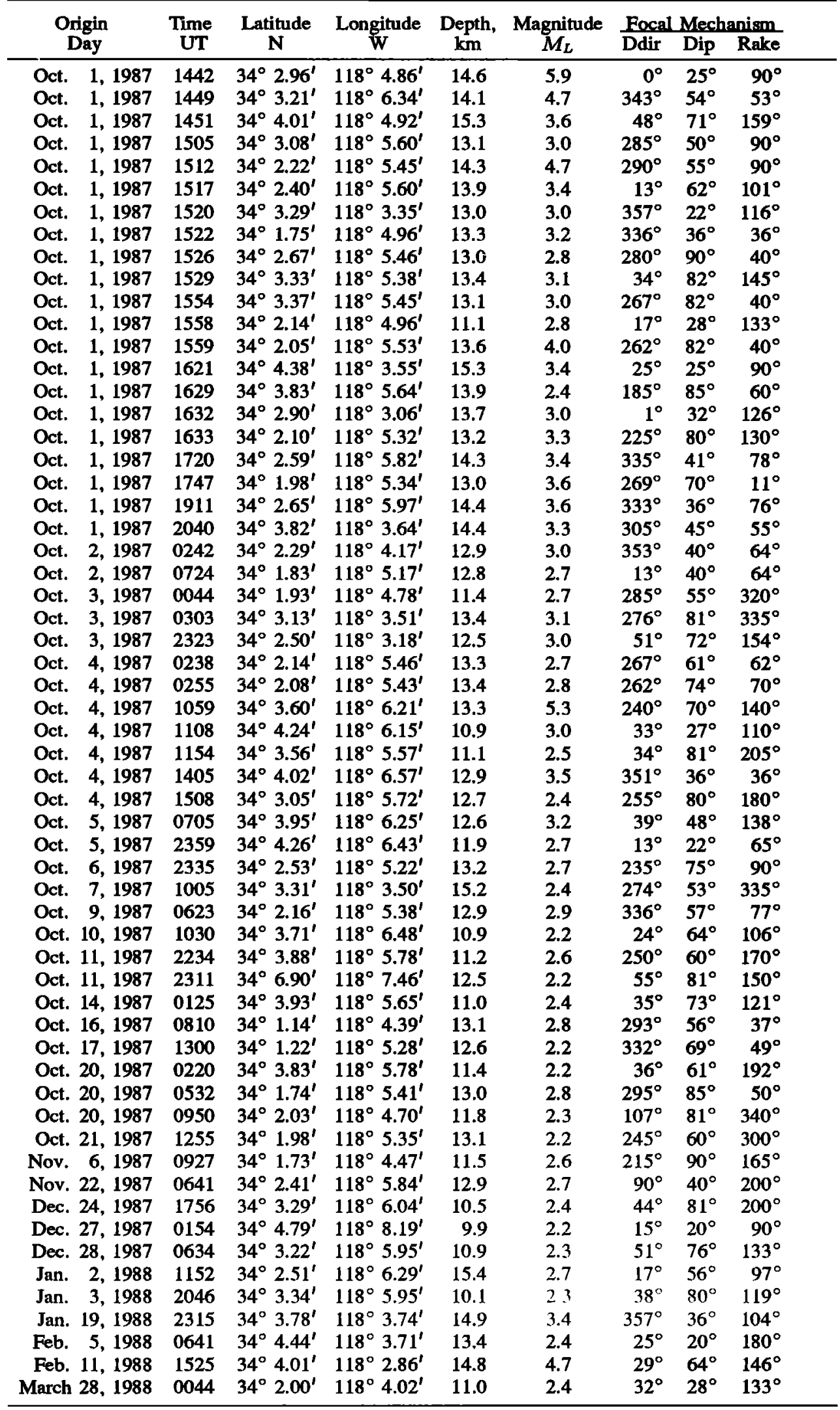




\section{WHITTIER NARROWS SEQUENCE}

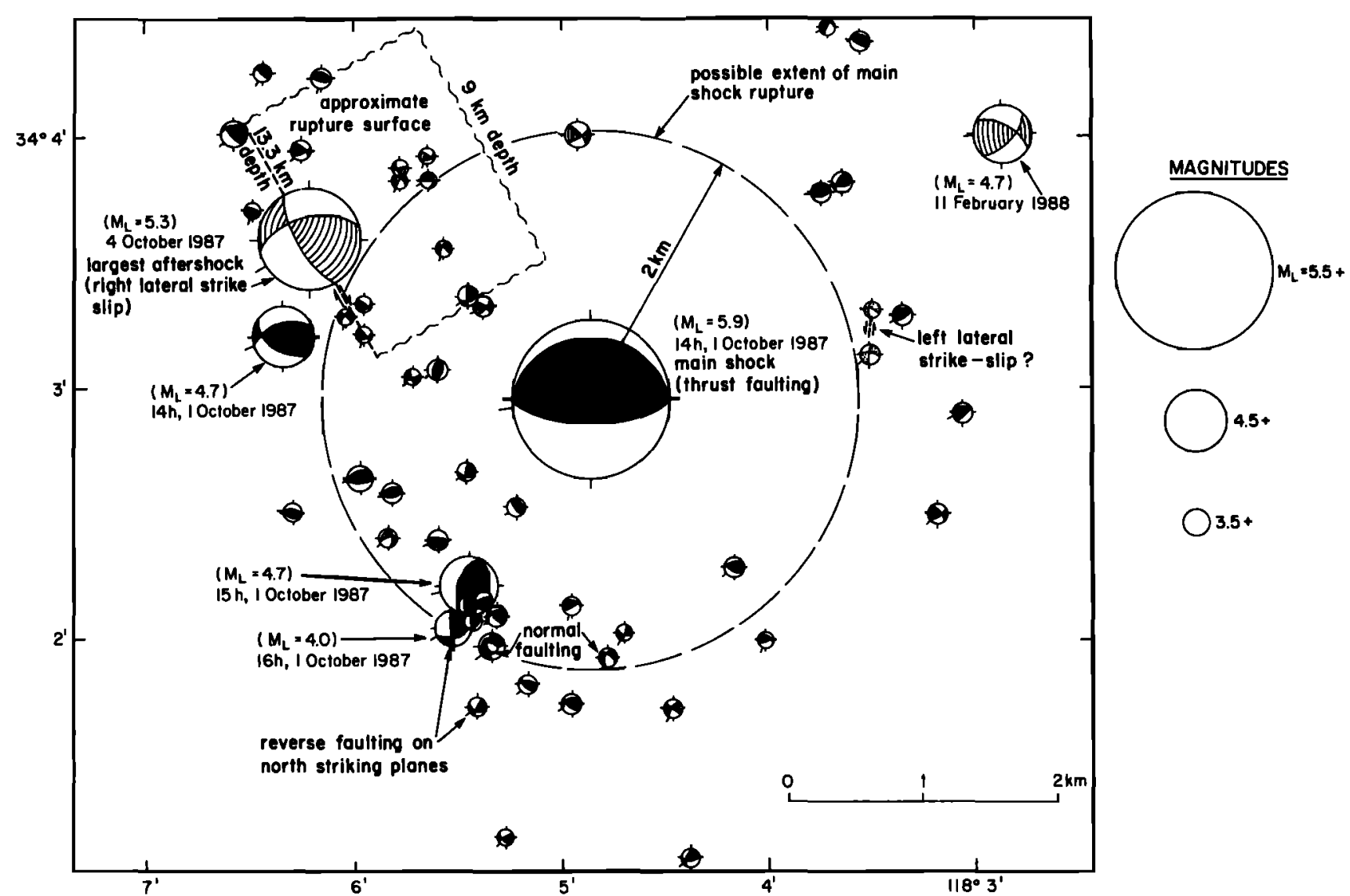

Fig. 12. Overview map of the lower hemisphere, single-event focal mechanisms of the mainshock and 58 aftershocks. Dates and magnitudes of the largest earthquakes are also included. Size of the mechanisms is proportional to magnitude. Compressional quadrants are shaded; thrust mechanisms have solid shading; strike-slip mechanisms have striped shading; and two possible left-lateral mechanisms have light dotted shading. For reference a circle of $2 \mathrm{~km}$ radius is drawn with center at the mainshock epicenter. The largest aftershock had a rupture surface dipping steeply to the west (see Figure 11), which is shown with dashed lines between depths of 9 and $13.3 \mathrm{~km}$.

mechanisms of the two events shows that the Whittier Narrows earthquake ruptured a gently dipping thrust fault, while the San Fernando event ruptured a more steeply dipping reverse fault (Figure 14). Figures $14 a$ and $14 b$ are slightly modified from Whitcomb et al. [1973]. Whitcomb et al. [1973] state that these are A and B quality locations of $M>3.0$ events that are felt by them to have an absolute location accuracy to $2 \mathrm{~km}$ horizontally and $4 \mathrm{~km}$ vertically and $4 \mathrm{~km}$ horizontally and $8 \mathrm{~km}$ vertically, respectively. They also point out that the relative location accuracies are much better and that depth determinations during the first 24 hours are less accurate than during the subsequent months when portable instruments were operated in the area. Only two of the shallow events, with depth less than $3 \mathrm{~km}$, occurred during the first 24 hours of aftershock activity. Hence the depth distribution of hypocenters in Figure $14 b$ is considered to be reliable. The greater depth $(14.6 \mathrm{~km})$ and limited depth range of the Whittier Narrows sequence suggest that it occurred on a blind thrust fault. The 8-12 $\mathrm{km}$ depth and steep dip of the San Femando earthquake and surface rupture suggest that it ruptured a reverse fault. This is also confirmed by spatial association with nearby reverse faults [Whitcomb et al., 1973]. Although these differences between the earthquakes exist, both appear to play a similar role in accommodating crustal deformation in southern California, because both result in crustal shortening accompanied by local uplift [Lin and Stein, this issue].

Although these two earthquakes differ in size and type of faulting, their aftershock sequences show surprising similarities. The San Fernando mainshock ruptured a northwest striking fault. Many of the San Fernando aftershocks, however, occurred along a linear northeast trend showing both reverse and left-lateral strike-slip motion on northeast striking planes. Whitcomb et al. [1973] interpreted these anomalous focal mechanisms as being caused by a step down to the west in the mainshock fault plane. Many of the Whittier Narrows aftershocks, including the largest aftershock $\left(M_{L}=5.3\right)$, formed a similar anomalous trend of reverse and right-lateral strikeslip mechanisms. To the south of the mainshock this 


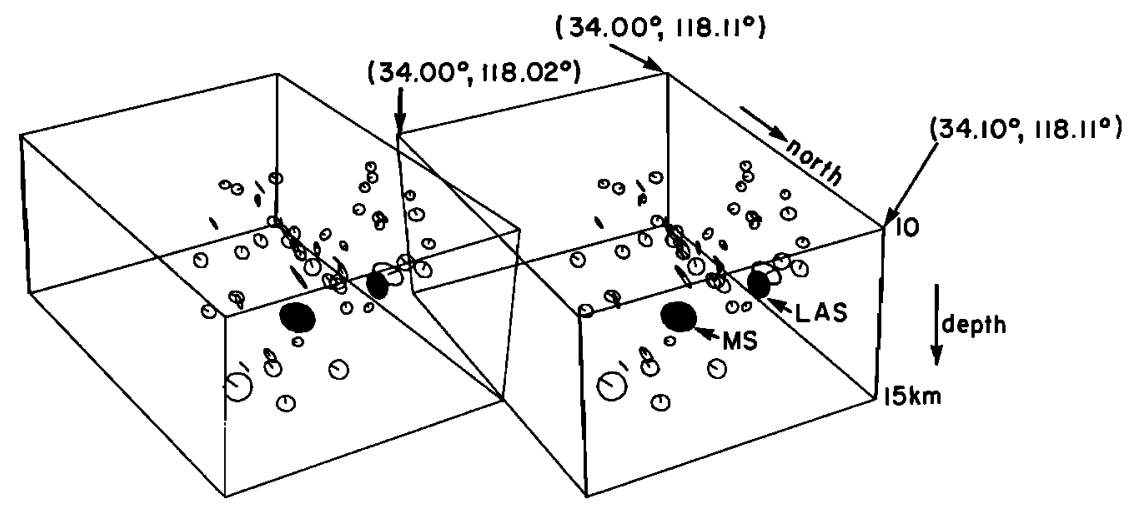

Fig. 13. Three-dimensional, stereoscopic projection of the focal mechanisms of the mainshock and 56 aftershocks in Figure 9. Each focal mechanism is represented by a circle oriented in the assumed plane of slip located at the hypocenter. The assumed slip plane was selected for each focal mechanisms as follows: north or west dipping planes from thrust mechanisms and right-lateral planes from strike-slip mechanisms except for two events on the east side where left-lateral planes are selected. The slip direction is indicated by the line segment within each circle. The view is from the $\mathrm{N} 30^{\circ} \mathrm{W}$, looking down from $30^{\circ}$ above the horizontal from a distance of $50 \mathrm{~km}$. The size of the circles is proportional to magnitude, and the mainshock and largest aftershock are labeled MS and LAS, respectively. This figure was prepared using a computer program written by D. Given and P. German (written communication, 1988).

trend strikes mostly north and is dominated by reverse faulting on north striking planes. To the north of the mainshock, however, the trend strikes more northwesterly and is dominated by right-lateral strike-slip faulting. These observations suggest that the thrust and reverse faults are geometrically complex and interaction between almost vertical and dipping faults is occurring. The almost vertical faults appear to be secondary structures that may control the location of the initiation of failure as well as the lateral extent of rupture on the dipping faults.

The tectonics of southern California west of the San Andreas fault are usually interpreted to consist of strikeslip faulting on northwesterly trending faults to the south of the Transverse Ranges. Within the Transverse Ranges the crustal deformation, however, is mostly accommodated by reverse or thrust faulting on west striking faults [Yerkes, 1985]. The boundary between these two tectonic provinces is usually drawn along the southernmost reverse faults such as the Santa Monica, Raymond, and Sierra Madre faults. In Figure 15, focal mechanisms for nine different $\left(M_{L} \geq 5.0\right)$ mainshocks that have occurred west of the San Andreas fault in southern California since 1933 are shown. These earthquakes are distributed over a large geographic area and are usually associated with low slip rate faults [Ziony and Yerkes, 1985]. Six of the nine events show reverse or thrust faulting within the Transverse Ranges. Only two events, the $1933\left(M_{w}=6.2\right)$ Long Beach earthquake and the $1981\left(M_{L}=5.3\right)$ Santa Barbara earthquake show strike-slip faulting [Woodward Clyde Consultants, 1979; Corbett, 1984]. The southernmost event in Figure 15 is the $1986\left(M_{L}=5.3\right)$ Oceanside earthquake that may have occurred on a bend or an offset in the San Diego Trough fault [Hauksson and Jones, 1988]. The geographic locations of the Whittier Narrows and the $1979\left(M_{L}=5.0\right)$ Malibu earthquakes suggest that reverse and thrust faulting along the southern margin of the Transverse Ranges extends $10-20 \mathrm{~km}$ to the south of the exposed reverse faults such as the Santa Monica and Sierra Madre faults, which previously were thought to form the southern margin of the Transverse Ranges. Thus the northern Los Angeles basin is subject to earthquake hazards from the exposed northwest striking strike-slip faults [Hauksson, 1987] as well as from buried west striking thrust faults.

The strike-slip faults are often well exposed at the surface, and the earthquake hazards can be quantified through detailed studies of the fault slip rates [Sieh, 1984]. In some cases, the reverse or thrust faults of the Transverse Ranges are also exposed at the surface and can be studied in the same manner as the strike-slip faults. In contrast, the Whittier Narrows earthquake and geologic interpretations by Davis et al. [this issue] raise the possibility of a system of buried thrust faults that present additional potential earthquake hazards to the Los Angeles metropolitan area. These faults differ from the exposed reverse or thrust faults that form the southern margin of the Santa Monica and San Gabriel mountains, in that they lie at depths of $10-15 \mathrm{~km}$ within the crystalline basement and below a thick sedimentary section, making direct study of them difficult. The deformational history recorded in the sedimentary section, however, commonly contains information about the offset and slip rate on these buried thrust faults [Davis and Hayden, 1987]. Furthermore, spatial distribution of small earthquakes [Hauksson, 1988] as well as secondary structural features within the sedimentary section may provide clues as to the size and segmentation of these deep thrust faults. Thus with additional study, it may be possible to quantify the potential earthquake hazards from these buried thrust faults.

The seismotectonic structure of the Whittier Narrows earthquake sequence closely resembles that of the 1983 Coalinga earthquake. That earthquake also occurred on a gently dipping thrust fault, the surface expression of 
I97I SAN FERNANDO
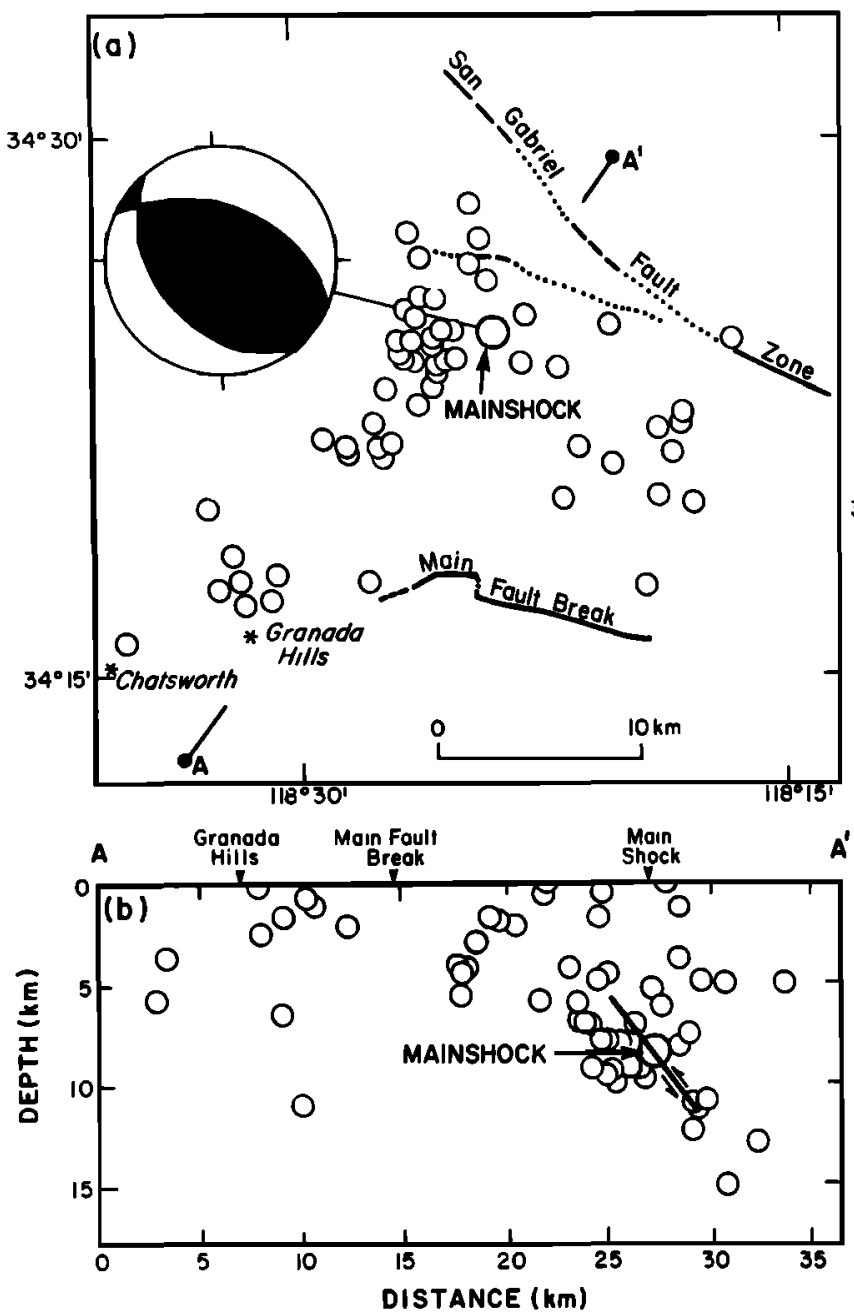

1987 WHITTIER NARROWS
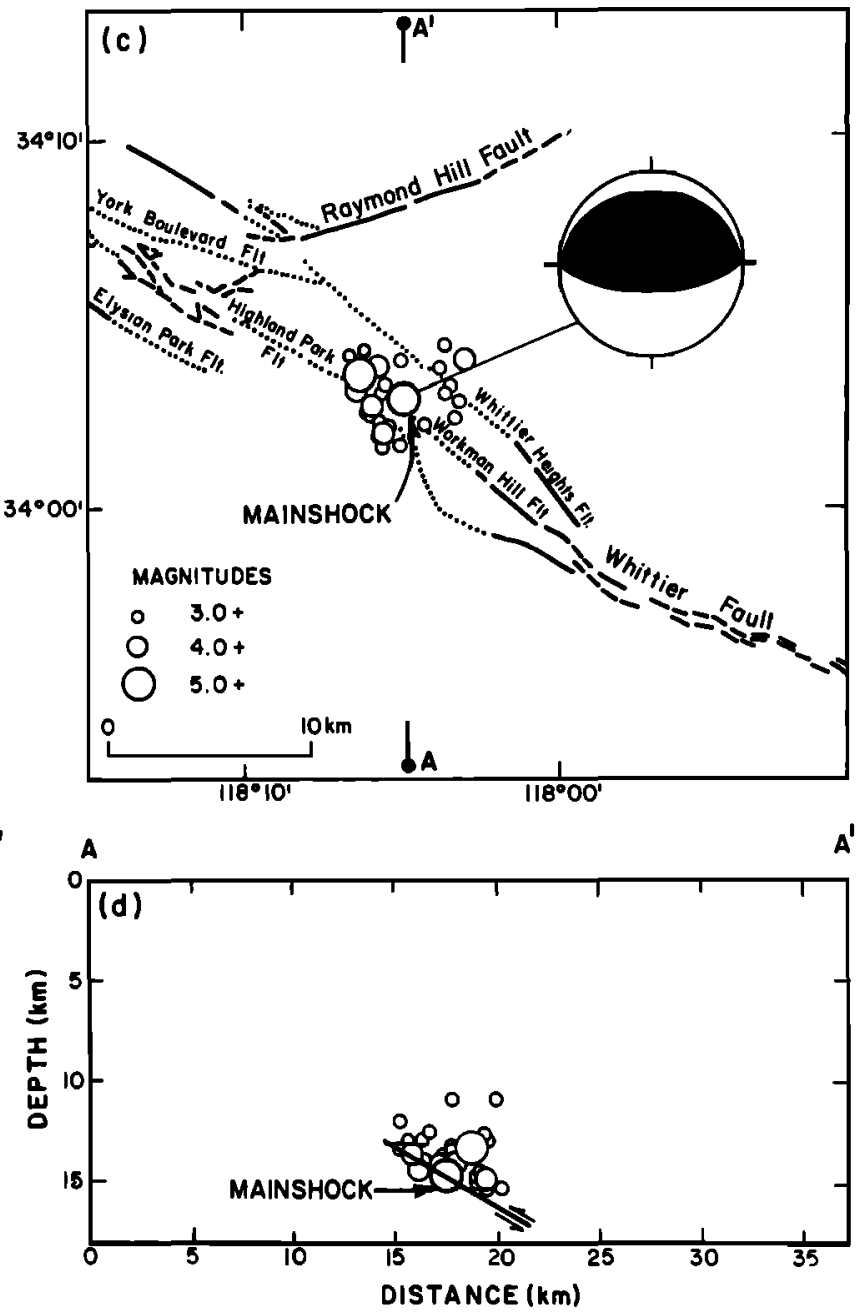

Fig. 14. Comparison of the 1971 San Fernando and the 1987 Whittier Narrows sequences. (a) The aftershock zone of $\left(M_{L} \geq 3.0\right)$ events, focal mechanism of the $\left(M_{w}=6.6\right)$ mainshock. (b) A depth cross section for the 1971 San Fernando sequence. The fault scarp "main fault break" produced during the mainshock is shown in map view. The north dipping nodal plane from the mainshock focal mechanism is also shown in the cross section [adapted from Whitcomb et al., 1973]. (c) The aftershock zone of $\left(M_{L} \geq 3.0\right)$ events and focal mechanism of the $\left(M_{L}=5.9\right)$ mainshock. (d) A depth cross section for the 1987 Whittier Narrows earthquake. The north dipping nodal plane from the mainshock focal mechanism is also shown in cross section. The faults are shown as dotted lines where concealed by alluvium or late Tertiary deposits, dashed lines where inferred, or solid lines where exposed. Faults near Whittier Narrows are from Lamar [1970].

which is an anticline [Eaton, 1985]. The Coalinga earthquake was one of three earthquakes to occur on adjacent segments of the same structure over 32 months. The sequence started with the $M_{L}=5.4$ New Idria earthquake in October $1982,20 \mathrm{~km}$ northwest of the Coalinga event [Scofield et al., 1985]. The $M_{L}=6.5$ Coalinga earthquake occurred in May 1983, and the $M_{L}=5.8$ Kettleman Hills earthquake followed in August 1985. Other types of faults, strike-slip and steeply dipping reverse faults, have also had consecutive rupture of adjacent segments within 1-2 years, such as the 1968 Borrego Mountain $\left(M_{L}=6.4\right)$ and 1969 Coyote Mountain $\left(M_{L}=5.8\right)$ earthquakes on the San Jacinto faults [Thatcher and Hamilton, 1973] and the 1947 Morongo Valley $\left(M_{L}=5.5\right)$ and 1948 Desert Hot Springs $\left(M_{L}=6.5\right)$ earthquakes on the Banning fault [Nicholson et al., 1986]. In some cases, the first earthquake is larger than the second, while in other cases, the second earthquake is larger. In all cases, the second earthquake has ruptured a different (but adjacent) segment of the same structure. Most Califomia earthquakes are not part of such multiple sequences, so there may not be another damaging earthquake soon on the Elysian Park fault system. However, the location of the Elysian Park antiform, where the segment of the fault adjacent to Whittier Narrows extends from Alhambra in the San Gabriel Valley west 


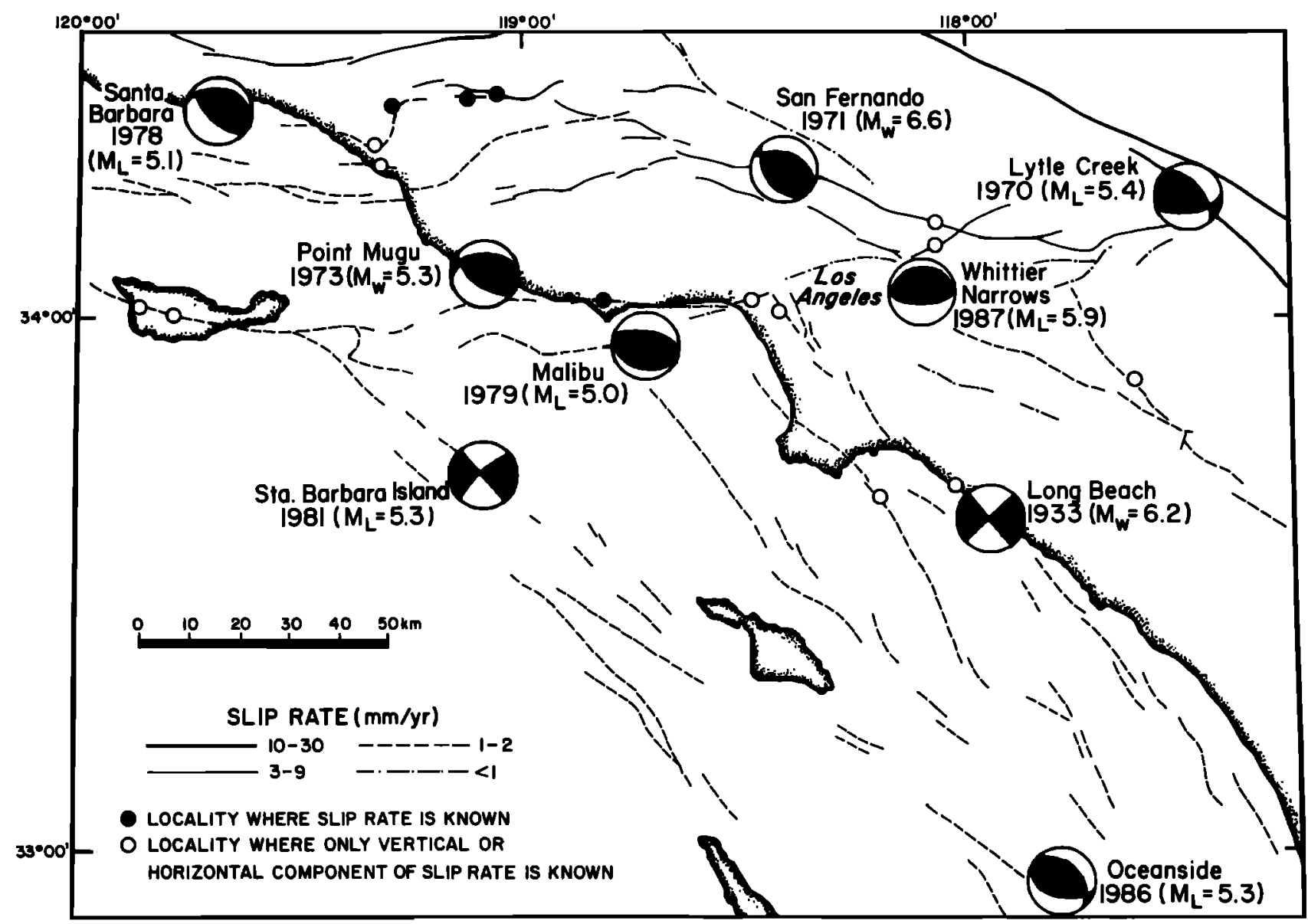

Fig. 15. Lower hemisphere, single-event focal mechanisms of moderate-sized earthquakes that have occurred west of the San Andreas fault in southern California. Compressional quadrants are shaded. Name or location, local magnitude, and year of occurrence are also shown. Slip rate information is from Ziony and Yerkes [1985]. Focal mechanisms are from Woodward-Clyde Consultants [1979], Jones [1984], Whitcomb et al. [1973], Stierman and Ellsworth [1976], Corbett and Johnson [1982], Hauksson and Saldivar [1986], Corbett [1984] and Hauksson and Jones [1988].

toward downtown Los Angeles, requires that the small probability of another earthquake occurring be seriously considered.

\section{ConClusions}

The 1987 Whittier Narrows mainshock and most of the aftershock focal mechanisms describe thrust faulting on a west striking plane with north over south movement, while the largest aftershock and several smaller aftershocks define a steeply dipping north to north-northwest striking fault that may have confined the slip of the mainshock. The presence of seismogenic buried thrusts beneath the northem Los Angeles basin shows that the thrust faulting and compressional regime of the Transverse Ranges extends further south than previously thought. The transition to the strike-slip regime of the Peninsular Ranges to the south does not occur abruptly at the southernmost mapped reverse fault but rather involves blind thrusts intermixing with the northernmost strikeslip faults. The Whittier Narrows aftershock sequence consisted of an unusually small number of aftershocks and most of the cumulative seismic moment release following the mainshock was accommodated by a few, large aftershocks. The occurrence of the Whittier Narrows earthquake demonstrates that the existing estimates of seismic hazards need to be reevaluated to include quantitative estimates of the earthquake potential of these buried thrust faults.

Acknowledgments. We are grateful to all of the people who were involved in the collection of data from this earthquake. Paul Spudich, Andy Michael, and Chuck Bufe all provided data from portable recording systems deployed during the aftershock sequence. Kate Hutton supplied the magnitude data and, of course, supervised the network processing at Caltech. Greg Perkins kindly provided the Whittier Narrows blast data. We have benefited from stimulating discussions about this earthquake with Thom Davis, Andy Michael, and Ross Stein. We thank Andy Michael, David Oppenheimer, Ross Stein, Chris Sanders, an anonymous reviewer, and John K. McRaney for critically reviewing the manuscript. This research was partially supported by USGS grant 14-08-0001-G1328 and USGS cooperative agreement 14-08-0001-A0264.

\section{REFERENCES}

Allen, R., Automatic phase pickers: Their present use and future prospects, Bull. Seismol. Soc. Am., 72, S225S242, 1982 . 
Bent, A. L., and D. V. Helmberger, Source complexity of the October 1, 1987, Whittier Narrows earthquake, $J$. Geophys. Res., this issue.

Borcherdt, R. D., J. B. Fletcher, E. G. Jensen, G. L. Maxwell, J. R. VanSchaack, R. E. Warrick, E. Cranswick, M. J. S. Johnston, and R. McClearn, A general earthquakeobservation system, GEOS, Bull. Seismol. Soc. Am., 75, 1783-1826, 1985.

Corbett, E. J., Seismicity and crustal structure studies of southem California: Tectonic implications from improved earthquake locations, Ph.D.thesis, 231 pp., Calif. Inst. of Technol., Pasadena, 1984.

Corbett, E. J., and C. E. Johnson, The Santa Barbara, California earthquake of 13 August 1978: Bull. Seismol. Soc. Am., 72, 2201-2226, 1982.

Crook, R., Jr., C. R. Allen, B. Kamb, C. M. Payne, and R. J. Proctor, Quatemary geology and seismic hazard of the Sierra Madre and associated faults, western San Gabriel Mountains, Recent Reverse Faulting in the Transverse Ranges, California, edited by D. M. Morton and R. F. Yerkes, U.S.Geol. Surv. Prof. Pap., 1339, 27-64, 1987.

Davis, T. L., and K. Hayden, A retrodeformable cross section across the central Los Angeles basin and implications for seismic risk evaluation (abstract) (EOS Trans. AGU, 68, $1502,1987$.

Davis, T. L., J.Namson, and R. F. Yerkes, A cross section of the Los Angeles area; Seismically active fold and thrust belt, the 1987 Whittier Narrows earthquake and earthquake hazard, J. Geophys. Res, this issue.

Dunne, W. M., and D. A. Ferrill, Blind thrust systems, Geology, 16, 33-36, 1988.

Eaton, J. P., Regional seismic background of the May 2, 1983 Coalinga earthquake, Proceedings of Workshop XXVII, Mechanics of the May 2, 1983 Coalinga Earthquake, edited by M. J. Rymer and W. L. Ellsworth, U.S. Geol. Surv. Open-File Rep., 85-44, 44-60, 1985.

Given, D. D., L. M. Jones, L. K. Hutton, and S. Hartzell, The Southern California Network Bulletin, July through December, 1986, U.S. Geol. Surv. Open-file Rep. 87-488, 27 pp., 1987.

Hadley, D., and H. Kanamori, Seismic structure of the Transverse Ranges, California, Geol. Soc. Am. Bull., 88, 1469-1478, 1977.

Hauksson, E., Seismotectonics of the Newport-Inglewood fault zone in the Los Angeles basin, southern California, Bull. Seismol. Soc. Am., 77, 539-561, 1987.

Hauksson, E., Thrust faulting and earthquake potential in the greater Los Angeles basin: (Abstract), Eos, Trans. AGU, $69,1305,1988$.

Hauksson, E., and L. M. Jones, The July 1986 Oceanside $\left(M_{L}=5.3\right)$ earthquake sequence in the Continental Borderland, southem California, Bull. Seismol. Soc. Am., 78, 1885-1906, 1988.

Hauksson, E., and G. V. Saldivar, The 1930 Santa Monica and the 1979 Malibu, Califomia, earthquakes, Bull. Seismol. Soc. Am., 76, 1542-1559, 1986.

Hauksson, E., et al., The 1987 Whittier Narrows earthquake in the Los Angeles metropolitan area, California, Science, 239, 1409-1412, 1988.

Heaton, T. H., and D. V. Helmberger, Generalized ray models of the San Fernando earthquake, Bull. Seismol. Soc. Am., 69, 1311-1341, 1979.

Jones, L. M., Foreshocks (1966-1980) in the San Andreas system, California, Bull. Seismol. Soc. Am., 74, 13611380, 1984

Jones, L. M., L. K. Hutton, D. D. Given, and C. R. Allen, The North Palm Springs, Califomia, earthquake sequence of July 1986, Bull. Seismol. Soc. Am., 76, 1830-1837, 1986.
Johnson, C. E., CUSP--Automated processing and management for large regional seismic networks, Earthquake Notes, 54, 13, 1983.

Kanamori, H., and C. R. Allen, Earthquake repeat time and average stress drop, in Earthquake Source Mechanics, Maurice Ewing Ser. Vol. 6, edited by S. Das, J. Boatwright, and C. H. Scholz, pp. 227-235, AGU, Washington, D. C., 1987.

Klein, F. W., User's guide to HYPOINVERSE, a program for VAX and PC350 computers to solve for earthquake locations, U.S. Geol. Surv., Open-File Rep., 85-515, Menlo Park, Califomia, 24 pp., 1985.

Lamar, D. L., Geology of the Elysian Park-Repetto Hills area, Los Angeles County, California, Spec. Rep., Calif. Div. Mines Geol., 101, 45 pp., 1970.

Lin, J., and R. Stein, Coseismic folding, earthquake recurrence, and the 1987 source mechanism at Whittier Narrows, Los Angeles basin, California J. Geophys. Res., this issue.

Morton, D. M., and R. F. Yerkes, Recent reverse faulting in the Transverse Ranges, California, Recent Reverse Faulting in the Transverse Ranges, California, edited by D. M. Morton and R. F. Yerkes, U.S. Geol. Surv. Prof. Pap., 1339, 1-4, 1987.

Nicholson, C., L. Seeber, P. Williams, and L. R. Sykes, Seismicity and fault kinematics through the eastern Transverse Ranges, California: Block rotation, strikeslip faulting, and low-angle thrust, J. Geophys. Res., 91, 4891-4908, 1986.

Page, B. M., The southern Coast Ranges, in The Geotectonic Development of California, Rubey vol. I, edited by W. G. Emst, Prentice Hall, Englewood Cliffs, NJ.,329-417, 1981.

Perkins, G., Data report for the 1987 seismic calibration/refraction survey, Whittier, Califomia, U.S. Geol. Surv., Menlo Park, California, 29 pp., 1988.

Reasenberg, P. A., and L. M. Jones, Earthquake hazard after mainshocks in California, Science, 243,1173-1176, 1989.

Reasenberg, P., and D. Oppenheimer, FPFIT, FPPLOT and FPPAGE: Fortran computer programs for calculating and displaying earthquake fault-plane solutions, U.S. Geol. Surv. Open-File Report 85-739, 46 pp., 1985.

Roecker, S., and W. L. Ellsworth, VELEST, Fortran Program, U.S. Geol. Surv., Menlo Park, Calif., 1978.

Scholz, C. H., The frequency-magnitude relation of microfracturing in rock and its relation to earthquakes, Bull. Seismol. Soc. Am., 58, 399-415, 1968.

Scholz, C. H., C. A. Aviles, and S. G. Wesnousky, Scaling differences between large interplate and intraplate earthquakes, Bull. Seismol. Soc. Am., 76, 65-70, 1986.

Scofield, C. P., W. H. Bakun, and A. G. Lindh, The 1982 New Idria, Califomia, earthquake sequence, in Proceedings of Workshop XXVII, Mechanics of the May 2, 1983 Coalinga Earthquake, edited by M. J. Rymer and W. L. Ellsworth, U.S. Geol. Surv. Open-file Rep., 85-44, 403$429,1985$.

Sieh, K. E., Lateral offsets and revised dates of large prehistoric earthquakes at Pallett Creek, southern California, J. Geophys. Res., 89, 7641-7670, 1984.

Stierman, D., and W. Ellsworth, Aftershocks of the February 21, 1973 Point Mugu, California, earthquake, Bull. Seismol. Soc. Am., 66, 1931-1952, 1976.

Thatcher, W., and R. M. Hamilton, Aftershocks and source characteristics of the 1969 Coyote Mountain earthquake, San Jacinto fault zone, California, Bull. Seismol. Soc. Am.,63, 647-661, 1973.

Utsu, T., Aftershocks and earthquake statistics, II, Analyses of the distribution of earthquakes in magnitude, time and 
space with special consideration to clustering characteristics of earthquake occurrence, J. Fac. Sci., Hokkaido Univ., 3(4), 379-441, 1971.

Wetmiller, R. J., R. B. Homer, H. S. Hasegawa, R. G. North, M. Lamontagne, D. H. Weichert, and S. G. Evans, An analysis of the 1985 Nahanni earthquakes, Bull. Seismol. Soc. Am., 78, 590-616, 1988.

Whitcomb, J. H., C. R. Allen, J. D. Garmany, and J. A. Hileman, San Fernando earthquakes series, 1971: Focal mechanisms and tectonics, Rev. Geophys., 11, 693-730, 1973.

Woodward-Clyde Consultants, Report on the evaluation of maximum earthquake and site ground motion parameters associated with the offshore zone of deformation, San Onofre Nuclear Generation Station, Los Angeles, California, 56 pp., report prepared for Southem Califomia Edison, Rosemead, Calif., 1979.

Yerkes, R. F., Geologic and seismologic setting, Evaluating Earthquake Hazards in the Los Angeles Region: An EarthScience Perspective, edited by J. I. Ziony, U.S. Geol. Surv. Prof. Pap., 1360, 25-41, 1985.
Yerkes, R. F., T. H. McCulloh, J. E. Schoellhamer, and J. G. Vedder, Geology of the Los Angeles basin California-An introduction, U.S. Geol. Surv. Prof Pap., 420-A, A1-A57, 1965.

Ziony, J. I., and R. F. Yerkes, Evaluating earthquake and surface-faulting potential, Evaluating Earthquake Hazards in the Los Angeles Region: An Earth-Science Perspective, edited by J. I. Ziony, U.S. Geol. Surv. Prof. Pap., 1360, 43-91, 1985.

E. Hauksson, Department of Geological Sciences, MC 0740, University of Southern California, Los Angeles, CA 90089-0740.

L. M. Jones, U.S. Geological Survey, 525 South Wilson Avenue, Pasadena, CA 91106.

(Received August 9, 1988; revised January 11, 1989; accepted January 14, 1989.) 